\title{
Avatars and Embodied Agents in Experimental Information Systems Research: A Systematic Review and Conceptual Framework
}

\author{
Hussain M. Aljaroodi \\ School of Electrical Engineering and Computing \\ University of Newcastle \\ Australia
}

Marc T. P. Adam

School of Electrical Engineering and Computing

University of Newcastle

Australia

\section{Raymond Chiong}

School of Electrical Engineering and Computing

University of Newcastle

Australia

Raymond.Chiong@newcastle.edu.au

Timm Teubner

Einstein Center Digital Future

Technical University of Berlin

Germany

\section{Abstract}

Computerised graphical representations of human users and computer agents, known as avatars and embodied agents, have been extensively explored and investigated in Information Systems (IS) research and practice. Such digital representations can be employed in either 2D or 3D. In order to facilitate research on user and agent representations and their applications in IS, we conduct a systematic literature review and establish the current state of research on humans' perceptions and behaviours when interacting with avatars and embodied agents. Our findings are based on an analysis of 90 articles published in top outlets in the IS field. This review identifies 1) different types of avatar and embodied agent-mediated interactions with users, 2) current application domains of such representations, 3) their dimensionality, 4) affected psychological constructs, and 5) practical considerations for the design of such digital representations. Finally, we discuss limitations of current research and, based on these, directions for future work.

Keywords: avatars, embodied agents, experiments, literature review

\section{Introduction}

To facilitate computer-mediated transactions at the nexus of the digital and physical world, user interface designers frequently employ design elements that resemble human features as digital representations of humans and computer agents. Digital representations of human users are commonly referred to as avatars, while representations of computer agents are referred to as embodied agents (Fox et al., 2015). In information systems (IS) research and practice, digital representations have successfully been employed in a wide range of 
applications, such as recommendation agents in e-commerce (S. Lee \& Choi, 2017; Qiu \& Benbasat, 2009), chat bots (Burgoon et al., 2016), tools for behavioural change (Sebastian \& Richards, 2017; Song, Kim, Kwon, \& Jung, 2013), and tutors in e-learning (Beege et al., 2017; Heidig \& Clarebout, 2011).

Over the past two decades, researchers have conducted experiments to better understand users' perceptions and behaviours in their interactions with avatars and embodied agents. Through experiments, researchers are able to observe actual interactions between users and avatars or embodied agents, and their responses to these interactions, under controlled conditions. Importantly, experiments allow researchers to identify causal effects through controlled variations, in order to see how different avatar and embodied agent design features affect outcome variables (Shadish et al., 2002). In this paper, we provide a state-of-the-art account of experimental research on human interaction with avatars and embodied agents in $2 \mathrm{D}$ as well as $3 \mathrm{D}$ environments by means of a systematic literature review (SLR), aiming to address the following overarching research question:

$R Q$ : What is the current body of knowledge in experimental IS research on design considerations, application contexts, behavioural outcomes, and influences on users' psychological constructs of avatars and embodied agents?

The review covers 90 articles published in top-tier IS journals and conferences. It provides an overview of users' perceptions of avatars and embodied agents, their effects on human behaviour, and how such graphical representations can be applied in a variety of settings to facilitate computer-mediated interactions between humans, avatars, and computer agents.

The main contributions of our SLR can be summarised as follows. First, we develop a framework that conceptualises design parameters of avatars and embodied agents, and various interaction types. These interaction types include a user interacting with their own avatar and a user interacting with another user's avatar or embodied agents. Second, we identify the application domains in which avatars and embodied agents are being employed. Third, we pinpoint key theories applicable to designing avatars and embodied agents. Fourth, we discern common design concepts and, fifth, identify methods used for investigating avatars, embodied agents, and their influence on users' perceptions and behaviours. This paper therefore may serve as a reference point for researchers working on experiments related to avatars and embodied agents, providing them with a guide on common design parameters and concepts as well as an overview of theories for understanding the interactions between humans, avatars, and embodied agents. For practitioners, this review may serve as a starting point for design considerations when employing avatars and embodied agents in practice.

The remainder of this paper is organised as follows. In Section 2, we describe the literature review methodology. We then outline the fundamentals of avatars and embodied agents in the context of IS research and establish a conceptual framework of digital representations of users or other entities (i.e., another person or a computer agent) in Section 3. ${ }^{1}$ Subsequently, in

1 Following the terminologies used by Ang et al. (2012), we use the term "avatar" to refer to an avatar representing another human being in the digital interaction. Note that other people's avatars are sometimes also referred to as personas in some studies (Vasalou \& Joinson, 2009). Clearly, what is a selfavatar and what is an avatar depends on the perspective that one takes, e.g., the user perceiving their own avatar (self-avatar) or that same avatar being perceived by another user (avatar). In other words, the distinction between self-avatars and avatars is mainly driven by the perspective one takes. 
Sections 4, 5, and 6, we summarise findings on self-avatars, avatars, and embodied agents, respectively. Finally, Section 7 concludes with a general discussion, implications for the use of avatars and embodied agents in practice, as well as directions for future research.

\section{Research Methodology of Literature Review}

This paper follows the methodological guidelines provided by Kitchenham \& Charters (2007) for performing an SLR. We focus on studies on avatars and embodied agents conducted under controlled laboratory and field settings with human participants. The process is divided into three distinct stages: plan, conduct, and report, as can be seen in Figure 1. In the plan stage, we identify the need for an SLR, develop a review strategy, and evaluate it. During the conduct stage, we then execute the search in databases, select appropriate studies, and analyse them. Finally, we document and report our findings in the report stage.

An initial exploratory search was conducted on Google Scholar using the search query "avatar" OR "virtual self" AND "experiment" as a starting point. While reviewing the obtained results, we extracted key terms used in these studies to further develop our search string. Next, we selected a well-established set of databases for conducting SLRs in the IS context (i.e., AIS Electronic Library, ScienceDirect, Taylor \& Francis Online, Wiley Online Library). We then performed a full-text search on these databases using ("avatar" OR "embodied agent" OR “virtual self" OR “virtual presence") AND “experiment".

The initial search string included the term virtual-self, as this concept is frequently considered in research on avatars and embodied agents, and is hence in line with the research question we would like to address in this literature review. After carefully screening through results of the initial search, we extended the search string to include characteristic terms that have appeared within the reviewed papers. Specifically, we included the concept of presence in the search string, as it represents one of the main constructs that is being investigated in digital representations and human interactions, and the term embodied agent was included too, as it refers to graphical representations of computer agents in the interaction and sometimes is used interchangeably with the term avatar. Finally, we constrained the search to include only experimental studies because of their potential to reveal actual interactions between humans, avatars and embodied agents under controlled conditions (see also the Introduction section).

We included all academic journals under the category of Information Management (IM) in the ABS Academic Journal Guide 2015 (ABS, 2015). In addition, we included full research papers published in two top IS conferences as recognised by ACPHIS (2013). ${ }^{2}$ In terms of selection criteria, we included only peer-reviewed papers reporting on experimental IS research with actual interactions between human participants and avatars or embodied agents. We excluded studies that 1) focused only on surveys without actual interactions between users and digital representations, 2) investigated robots rather than virtual representations, 3) included disembodied, that is, non-graphical representations, or 4) were research-in-progress.

\footnotetext{
${ }^{2}$ Conferences included are the International Conference on Information System (ICIS) and European Conference on Information System (ECIS). These two conferences were selected as they were ranked A by IFIP (2015).
} 


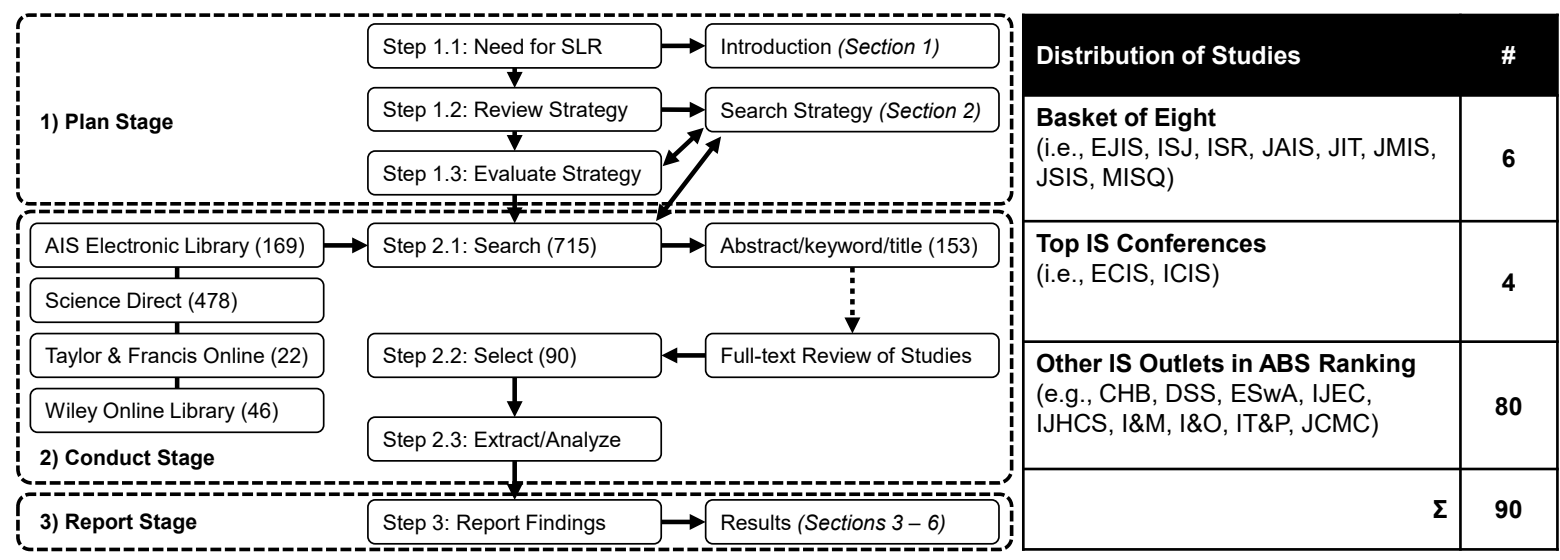

Figure 1. Stages of the SLR and distribution of studies

We used the defined search string and searched the title, abstract, and keywords of studies in the selected databases. This search resulted in 715 hits (see the conduct stage in Figure 1), of which 625 were journal publications and 90 were conference publications. Then, the first and second authors independently screened the title, abstract, and keywords against the research question and selection criteria to identify relevant papers for the review. The agreement rate between the two authors was $94.97 \%$ (679 out of the 715 papers). Discrepancies were resolved by discussion with the fourth author (36 papers, 15 included, 21 excluded). Finally, the first author performed a full text review on the studies, resulting in 90 research papers (86 from journals, 4 from conferences). Table A1 in the Appendix provides an overview of all included studies, providing concise information on the specific type of interaction, dimensionality, context, psychological constructs, environments, and sample size for each study.

\section{Conceptual Framework}

According to Representation Theory (RT), the fundamental purpose of an IS is to provide users with a faithful representation of some real-world phenomena (Recker et al., 2019). The main tenets of RT posit that IS will 1) be employed if they provide users with a more cost-effective way to obtain knowledge about a focal real-world phenomenon than observing it directly, and 2) yield higher usefulness the more faithful the phenomena are represented. Common examples for the application of RT include data modelling, object-oriented modelling, and process modelling (Burton-Jones et al., 2017; Recker et al., 2019). Similar notions can be applied when it comes to avatar design: An avatar provides a digital representation of a person in the real-world, while an embodied agent represents a computer agent. Employing these representations can increase cost-effectiveness, e.g., in the provision of health and education services over a distance and/or to a large audience (Beege et al., 2017; Heidig \& Clarebout, 2011; Noorbergen, Adam, Attia, Cornforth, \& Minichiello, 2019); it may also increase faithfulness of the representation, as avatars usually have human features that capture the naturalness of interpersonal encounters in the real-world (Nowak \& Rauh, 2006).

In this paper, we distinguish two perspectives in terms of human interactions with avatars, namely self and other. The "self" perspective refers to a user's interaction with their own avatar, often involving facial and body features, gestures, sound, or other forms of behaviour and expression. Following this perspective, the avatar is referred to as a self-avatar (Vasalou \& Joinson, 2009). The "other" perspective refers to a user's view on other humans (computer agents) represented by avatars (embodied agents). 
Through their self-avatars, users may directly or indirectly engage with others. Based on the different spheres and levels of interactions, we develop a conceptual framework that differentiates between five different interaction types, as shown in Figure 2. From the figure, we see that interactions with avatars can be distinguished as human-to-self-avatar (H2SA), human-to-avatar (H2A), and self-avatar-to-avatar (SA2A). Similarly, humans may interact with embodied agents directly (human-to-embodied-agent, H2EA) or through their avatars (selfavatar-to-embodied-agent, SA2EA). Among the 90 reviewed studies, a majority considered SA2A (34), followed by H2A (21), H2EA (20), H2SA (17), and SA2EA (8) interactions. Note that here the total adds up to more than 90 because some studies have investigated more than one interaction type. The framework captures commonly examined psychological constructs for specific interaction types. Table 1 provides definitions for the psychological constructs that appear in the framework and their usage in different types of interactions.



Figure 2. Conceptual framework of digital representations and their interactions

Note: All icons used have been sourced from SVG Silh and Pixabay (https://svgsilh.com \& https://pixabay.com; Creative Commons CC0 1.0). The greyed-out icons are not considered in the respective interaction type. For readability, only constructs that are used by at least two studies are shown. Realism includes behavioural, emotional, or visual realism. The complete list of constructs can be found in Table A1 in Appendix A. 


\begin{tabular}{|c|c|c|}
\hline Constructs & Description & Usage \\
\hline Anthropomorphism & $\begin{array}{l}\text { The degree of humanness } \\
\text { of the digital } \\
\text { representation as } \\
\text { perceived by the user }\end{array}$ & $\begin{array}{l}\text { H2A: Nowak et al. (2015); Nowak \& Rauh }(2006,2008) \\
\text { H2EA: Y. Kim \& Sundar (2012a); Krämer et al. }(2013)\end{array}$ \\
\hline Attractiveness & $\begin{array}{l}\text { The degree of } \\
\text { attractiveness of the } \\
\text { digital representation as } \\
\text { perceived by the user }\end{array}$ & $\begin{array}{l}\text { H2A: Keng \& Liu (2013); Leding et al. (2015); Nowak et al. } \\
\text { (2015); Nowak \& Rauh (2006); Westerman et al. (2015) } \\
\text { H2EA: Burgoon et al. (2016) }\end{array}$ \\
\hline Credibility & $\begin{array}{l}\text { The degree to which the } \\
\text { digital representation is } \\
\text { perceived as believable }\end{array}$ & $\begin{array}{l}\text { H2A: Nowak et al. (2015); Nowak \& Rauh }(2006,2008) \\
\text { H2EA: Y. Kim \& Sundar (2012a) }\end{array}$ \\
\hline Enjoyment & $\begin{array}{l}\text { The degree to which the } \\
\text { user enjoys the interaction } \\
\text { with the digital } \\
\text { representation }\end{array}$ & $\begin{array}{l}\text { H2A: Li \& Lwin (2016); Rodrigues et al. (2016) } \\
\text { H2EA: S. Lee \& Choi (2017); Qiu \& Benbasat }(2009,2010) \\
\text { SA2A: Guadagno et al. (2011); Song Kim, Kwon, et al. (2013) } \\
\text { SA2EA: Guadagno et al. (2011); Jin (2010) }\end{array}$ \\
\hline Identification & $\begin{array}{l}\text { The degree to which a } \\
\text { user identifies themselves } \\
\text { with the digital } \\
\text { representation }\end{array}$ & H2SA: Seo et al. (2017); Song, Kim, Kwon, et al. (2013) \\
\hline Immersion & $\begin{array}{l}\text { The degree to which a } \\
\text { user feels immersed in the } \\
\text { virtual environment } \\
\text { during the interaction } \\
\text { with the digital } \\
\text { representation }\end{array}$ & $\begin{array}{l}\frac{\text { SA2A: Gerhard et al., (2004); Goel et al. (2013); Grinberg et al. }}{(2014)} \\
\text { SA2EA: Gerhard et al. (2004) }\end{array}$ \\
\hline Intention to use & $\begin{array}{l}\text { The user's intention to use } \\
\text { the digital representation }\end{array}$ & $\begin{array}{l}\text { H2A: Y. Lee et al. (2009); Nowak \& Rauh (2006); Rodrigues et al. } \\
\text { (2016); Westerman et al. (2015) } \\
\text { H2EA: Gong (2007); S. Lee \& Choi (2017); Qiu \& Benbasat (2009, } \\
\text { 2010) } \\
\text { H2SA: Fox et al. (2013); Suh et al. (2011) } \\
\underline{\text { SA2A: Fox et al. (2013); Galanxhi \& Nah (2007); Lester \& King }} \\
\text { (2009) }\end{array}$ \\
\hline Likeability & $\begin{array}{l}\text { The degree to which the } \\
\text { user likes the digital } \\
\text { representation }\end{array}$ & $\begin{array}{l}\text { H2A: Bacev-Giles \& Haji (2017) } \\
\text { H2EA: Brave et al. (2005); Gong (2007); Groom et al. (2009); } \\
\text { Kang \& Gratch (2014); Nunamaker et al. (2011) } \\
\text { SA2A: Ang et al. (2013); Guadagno et al. (2011); Hanus \& Fox } \\
\text { (2015) } \\
\text { SA2EA: Guadagno et al. (2011) }\end{array}$ \\
\hline Presence & $\begin{array}{l}\text { The degree to which a } \\
\text { user feels present in the } \\
\text { virtual environment with } \\
\text { the digital representation }\end{array}$ & $\begin{array}{l}\text { H2A: Kang \& Watt (2013); Y. Lee et al. (2009); Li \& Lwin (2016); } \\
\text { Rodrigues et al. (2016) } \\
\text { H2EA: Kang \& Gratch (2014); Y. Kim \& Sundar (2012a); Qiu \& } \\
\text { Benbasat (2009, 2010) } \\
\text { H2SA: Fox et al. (2013); Seo et al. (2017); Won et al. (2015) } \\
\text { SA2A: Felnhofer et al. (2018, 2014); Fox et al. (2013); Franceschi } \\
\text { et al. (2009); Gerhard et al. (2004); Grinberg et al. (2014); } \\
\text { Guadagno et al. (2011); Guegan et al. (2017); Hammick \& Lee } \\
\text { (2014); Jin (2012); Kohonen-aho \& Tiilikainen (2017); Ratan \& } \\
\text { Sah (2015); Sutcliffe \& Alrayes (2012); Wu et al. (2015) } \\
\text { SA2EA: Felnhofer et al. (2018); Gerhard et al. (2004); Guadagno } \\
\text { et al. (2011); Kohonen-aho \& Tiilikainen (2017) }\end{array}$ \\
\hline
\end{tabular}




\begin{tabular}{|l|l|l|}
\hline \multicolumn{1}{|c|}{ Constructs } & \multicolumn{1}{|c|}{ Description } & \multicolumn{1}{c|}{ Usage } \\
\hline Similarity & $\begin{array}{l}\text { The degree to which the } \\
\text { user perceives that the } \\
\text { digital representation is } \\
\text { similar to them }\end{array}$ & $\begin{array}{l}\text { H2A: Bacev-Giles \& Haji (2017); J. Kim (2011); Nowak \& Rauh } \\
\text { (2006); Wrzesien et al. (2015) } \\
\text { H2EA: Beege et al. (2017; Tamborini et al. (2018) } \\
\text { H2SA: Seo et al. (2017); Suh et al. (2011); Vasalou \& Joinson } \\
\text { (2009); Wrzesien et al. (2015) } \\
\text { SA2A: Dolgov et al. (2014); Fehrenbacher \& Weisner (2017); }\end{array}$ \\
\hline $\begin{array}{l}\text { Trust } \\
\text { Guegan et al. (2016); H.-K. Kim \& Kim (2016); J. Kim (2009); J. } \\
\text { Kim \& Park (2011); Martens et al. (2018); Spence et al. (2013); } \\
\text { Westerman et al. (2015) }\end{array}$ \\
$\begin{array}{l}\text { The degree to which the } \\
\text { considered trustworthy by representation is } \\
\text { the user }\end{array}$ & $\begin{array}{l}\text { H2A: Balas \& Pacella (2017); Nowak et al. (2015) } \\
\text { H2EA: Brave et al. (2005); Gong (2007); Nunamaker et al. (2011); } \\
\text { Qiu \& Benbasat (2009); Riedl et al. (2011, 2014); Tamborini et al. } \\
\text { (2018) } \\
\text { SA2A: Ang et al. (2013); Fehrenbacher \& Weisner (2017); }\end{array}$ \\
$\begin{array}{ll}\text { Galanxhi \& Nah (2007); Guadagno et al. (2011); Jin (2012) } \\
\text { SA2EA: Guadagno et al. (2011) }\end{array}$
\end{tabular}

Table 1. Definitions of constructs and their usage in different interaction types

\subsection{Avatars}

Previous research has studied generic avatars (e.g., Franceschi et al., 2009), customised avatars (e.g., Nowak et al., 2015), or a combination of both (e.g., Suh et al., 2011). Generic avatars are pre-created with some characteristics such as gender, but cannot be customised by users (Dolgov et al., 2014; Ratan \& Sah, 2015). Customised avatars, in contrast, allow users to make deliberate choices on appearance (Guegan et al., 2016).

In H2SA interaction, a user controls the movement and/or appearance of their self-avatar by some controlling device (Pessoa et al., 2014). Note that H2SA does not necessarily involve other users' avatars. Here, the interaction between the user and their self-avatar often only expresses the user's inputs through the avatar (Won et al., 2015). In H2A interactions, users interact with others' avatars. They may, for instance, observe the avatar's appearance and behaviour and implicitly evaluate the entity behind it (Nowak \& Rauh, 2008). In SA2A interaction, human users control their respective avatars to interact with others through them (e.g., Sutcliffe \& Alrayes, 2012). Typical purposes are collaborations and meetings in business contexts (Guegan et al., 2017; Huang et al., 2010), collaborative problem solving (Guegan et al., 2016), or multi-person entertainment (Dolgov et al., 2014; Martens et al., 2018).

\subsection{Embodied Agents}

Embodiment refers to the visual representation of an abstract idea, a thing, or a person (Taylor, 2002). An embodied agent, in this sense, describes "a perceptible digital representation whose behaviours reflect a computational algorithm designed to accomplish a specific goal or set of goals" (Bailenson \& Blascovich, 2004, p. 64). The majority of the reviewed studies investigated embodied agents that exhibit at least some human-like features. In this context, anthropomorphism refers to the degree of humanness of embodied agents, that is, "the extent to which an image is perceived to resemble human characteristics and has human morphology" (Nowak \& Rauh, 2006, p. 154). Exemplary applications include the provision of information (Carlotto \& Jaques, 2016), product recommendations in e-commerce (Qiu \& Benbasat, 2009), or screening interviews (e.g., Nunamaker et al., 2011). In SA2EA interaction, a user controls an avatar and interacts with an embodied agent through their avatar. Common 
examples can be found in automated business processes such as job interviews or information delivery (Y. Kim \& Sundar, 2012b).

\subsection{Artefact Design}

For digital representations of humans, Davis et al. (2009) identified three main factors that affect people's perception of self-avatars and (others') avatars. These are 1) avatar appearance, 2) perceived presence (i.e., the sense of being in an environment with another person) (Steuer, 1992; Won et al., 2015), and 3) immersion (i.e., users' perception to be interacting with the virtual environment rather than their physical environment) (Guadagno et al., 2007). These factors are inherently different to those in the human perception of embodied agents.

Our conceptual framework provides an overview of the different forms of appearances employed in the reviewed studies. It considers the dimensionality in which the interaction takes place (i.e., 2D and/or 3D), the dynamics of the visual interaction (i.e., static, motion), and the overall level of embodiment (i.e., face only, half body, full body). Furthermore, the framework lists a number of design considerations for the different types of digital representations that will be further explored in the subsequent sections. Table 2 summarises the artefact design that has been considered for different interaction types.

\begin{tabular}{|c|c|c|c|c|c|c|c|}
\hline \multirow{2}{*}{\multicolumn{2}{|c|}{ Artefact Design }} & \multicolumn{5}{|c|}{ Interaction Type } & \multirow{3}{*}{$\begin{array}{c}\text { Total } \\
66\end{array}$} \\
\hline & & \multirow{2}{*}{$\frac{\text { H2SA }}{15}$} & \multirow{2}{*}{$\frac{\text { SA2A }}{30}$} & \multirow{2}{*}{$\frac{\text { SA2EA }}{8}$} & \multirow{2}{*}{$\frac{\text { H2A }}{6}$} & \multirow{2}{*}{$\frac{\text { H2EA }}{7}$} & \\
\hline \multirow{3}{*}{ Body } & Full & & & & & & \\
\hline & Half & 0 & 0 & 0 & 5 & 7 & 12 \\
\hline & Face only & 2 & 4 & 0 & 6 & 6 & 18 \\
\hline \multirow{2}{*}{ Dynamics } & Static & 3 & 4 & 0 & 12 & 5 & 24 \\
\hline & Motion & 14 & 30 & 8 & 6 & 15 & 73 \\
\hline \multirow{2}{*}{ Dimensionality } & $2 \mathrm{D}$ & 2 & 6 & 0 & 10 & 9 & 27 \\
\hline & $3 \mathrm{D}$ & 16 & 31 & 8 & 8 & 12 & 75 \\
\hline \multicolumn{2}{|r|}{ Total } & 52 & 105 & 24 & 53 & 61 & \\
\hline
\end{tabular}

Table 2. Artefact design for different interaction types

Note: Numbers here refer to the number of studies for the respective artefact design and interaction type. The total number adds up to more than 90 , due to the fact that some studies have investigated more than one interaction type or artefact design.

One important aspect in this regard is customisation (e.g., Guadagno et al. 2011; Nowak \& Rauh, 2008). Customisability refers to the possibility to design and modify an avatar's appearance (Behm-Morawitz, 2013), that is, the degree "to which [it] can be created, selected, or changed to comply with user preferences" (Teng, 2010, p. 1549). In 36 out of the 90 reviewed studies, researchers allowed participants to customise their self-avatars with personalised features (e.g., see Vasalou \& Joinson, 2009). In other experimental settings, the degree of visual realism of an avatar is controlled to achieve specific interactional outcomes, for instance, to increase avatars' credibility (e.g., Nowak \& Rauh, 2006). Here, self-avatars may depict photorealistic, fictional, or supernatural characters (Vasalou \& Joinson, 2009).

\subsection{Presence and Immersion}

One central concept for understanding avatars and embodied agents is presence. In our framework, it represents one of the most frequently-investigated constructs. Digital interaction is generally considered an unnatural way of human communication, as the interaction partners are separated physically (Carter et al., 2015; Grudin, 2001). However, avatars can be used to establish presence anyway (Kang \& Watt, 2013), that is, user A's sense of being in an 
environment with user $\mathrm{B}$, where users are digitally represented across space or time, and react to each other or to stimuli (Heeter, 1992; Steuer, 1992; Won et al., 2015). There are different concepts of presence, which include individual-, physical-, social-, co-, tele-, and virtual presence (see Franceschi et al. (2009) and Nowak \& Biocca (2003) for details).

Closely related to presence, immersion refers to the degree to which users experience being within a virtual rather than in their actual physical environment (Guadagno et al., 2007). Realistic environments yield higher presence, which in turn lead to higher immersion (Guadagno et al., 2007; Jin, 2012). In gaming, for example, Teng (2010) found that higher immersion enhances user loyalty to the game. Immersed users can also be more socially engaged (Grinberg et al., 2014). ${ }^{3}$

\subsection{Experimental Research on Avatars and Embodied Agents}

Laboratory and field experiments are typically employed to investigate human behaviour when interacting with avatars and embodied agents. In fact, the majority of experimental studies in the field of IS involving avatars or embodied agents have been conducted in laboratory settings, where researchers are able to tightly control environmental parameters, mitigate confounding effects, and thus can establish causality of effects between system design and human perceptions, physiology, and behaviour. In our SLR, for example, as many as 84 studies were conducted in laboratory environments, while only five studies were conducted in the field and one based on both laboratory and field experiments. The six studies that conducted field experiments controlled different aspects of real-world settings. These include customers of an electronic banking application (Rodrigues et al., 2016), self-tracking of physical activities in users' everyday environments (Sanchez-Valdes \& Trivino, 2015), airport security screenings (Nunamaker et al., 2011), and students' performance, engagement, and presence in an online course (Barata et al., 2017; Franceschi et al., 2009; Lester \& King, 2009).

\subsection{Application Contexts}

Avatars and embodied agents have become widely used as design elements in IS research. By providing a graphical representation of humans and computer agents, they have been shown to create positive user experience (e.g., usability, collaboration), support learning processes (e.g., performance, engagement), and facilitate behavioural intention (e.g., physical activity, usage intention, purchase intention) in a wide range of applications. Based on the studies we reviewed, the application contexts include business, education, entertainment, health, and social interaction. Table 3 summarises the number of studies for each application context and interaction type.

\footnotetext{
${ }^{3}$ Importantly, the use of avatars can also increase involvement and trust between users behind the avatars. The outlined concepts of presence and immersion are central to research on avatars, and we will repeatedly use and refer back to these notions in the subsequent sections.
} 


\begin{tabular}{|l|c|c|c|c|c|c|}
\hline \multirow{2}{*}{ Context } & \multicolumn{5}{|c|}{ Interaction Type } & \multirow{2}{*}{ Total } \\
\cline { 2 - 6 } & H2SA & SA2A & SA2EA & H2A & H2EA & \\
\hline Business & 1 & 6 & 1 & 6 & 8 & $\mathbf{2 2}$ \\
\hline Education & 3 & 5 & 0 & 1 & 1 & $\mathbf{1 0}$ \\
\hline Entertainment & 6 & 8 & 1 & 1 & 5 & $\mathbf{2 1}$ \\
\hline Health & 2 & 0 & 2 & 1 & 1 & $\mathbf{6}$ \\
\hline Social & 5 & 15 & 4 & 9 & 3 & $\mathbf{3 6}$ \\
\hline & $\mathbf{1 7}$ & $\mathbf{3 4}$ & $\mathbf{8}$ & $\mathbf{1 8}$ & $\mathbf{1 8}$ & \\
\hline
\end{tabular}

Table 3. Application contexts for different interaction types

Note: Numbers here refer to the number of studies for the respective context and interaction type. The total number adds up to more than 90 , due to the fact that some studies have investigated more than one interaction type for the respective context.

\section{Interaction with Self-Avatars}

\subsection{Self-Avatar Concepts}

Digital environments enable users to interact and communicate in ways that go beyond those of traditional channels (Goel et al., 2013; Hämäläinen et al., 2008; Mccreery et al., 2012). To do so, they need to represent themselves therein (Mallan, 2009). Self-avatars function as tools for representation, immersion, and interaction with others in virtual worlds (Ducheneaut et al., 2009; Koles \& Nagy, 2012). This section synthesises the results of studies on a user's interaction with their own avatar, covering the design dimensions customisability, realism, and time, as well as the avatar's effects on user perceptions and behaviour. Overall, 11 studies $(13.1 \%$ based on our SLR) considered H2SA interactions in different contexts such as health (H. E. Kim et al., 2017; Sanchez-Valdes \& Trivino, 2015), business and entertainment (Kaye et al., 2018; Peña \& Chen, 2017; Won et al., 2015), and education and social interaction (Seo et al., 2017; Song, Kim, Kwon, et al., 2013; Vasalou et al., 2008; Vasalou \& Joinson, 2009).

For the dimension of time, some avatar concepts refer to a future state of the represented person (Song, Kim, Kwon, et al., 2013), while avatars in a now state refer to the current or currently desired state. A special case of future self-avatars is the idealistic representation. Based on the self-idealism paradigm, an ideal self refers to what the user aims to become in the future and may include aspects of education, socialisation, role models, societal norms, and preferences (Dunn \& Guadagno, 2012).

For the dimension of realism, there are mirrored and fictional representations (e.g., Peña et al., 2016; Suh et al., 2011; Vasalou \& Joinson, 2009). The concept of a mirrored self refers to selfavatars that resemble the actual person as much as possible (Vasalou et al., 2008), which may include mirrored behaviours and gestures, representing aspects of the user in the real world (Burton-Jones et al., 2017; Recker et al., 2019). It can be seen as a simulated, mirror version of the self, and reflective of the offline self, as well as has the potential to influence the individual in meaningful ways. For example, previous research has demonstrated that avatars that show the consequences of smoking by means of altered physical appearance are capable of creating a sense of risks associated with smoking (Song, Kim, Kwon, et al., 2013).

The concept of fictional self, in contrast, represents the user as a fictional, possibly fantastic character. Users may represent themselves as fictional characters to escape from their actual selves (Greenwood, 2008), or to gain new perspectives, experiences, and knowledge (Shedlosky-Shoemaker et al., 2014). For example, a user may hide their identity and use an authoritative or persuasive avatar for a new role. 


\subsection{Influences on User Perceptions and Behaviours}

While much research considers how one user's avatar affects other users, a user's (self-) avatar can also affect their own perceptions and behaviours in the virtual environment and in the real world (Yee et al., 2009). This phenomenon is known as the Proteus effect (Yee \& Bailenson, 2007). The effect is rooted in self-perception theory (Yee et al., 2009), positing that there will be modifications in self-perception based on the behaviour and/or characteristics of a user's avatar (Fox et al., 2013). For instance, users may adopt new behaviours (desirable or undesirable) from their self-avatars (Fox \& Ahn, 2012; Seo et al., 2017), and exhibit increased confidence and willingness to disclose information when being represented by attractive selfavatars (Yee and Bailenson, 2007). Also, users exhibit increased physical activity when represented by athletic instead of obese self-avatars (Peña \& Kim, 2014). To understand the Proteus effect, it is important to consider how the characteristics of a user's avatar affect behaviour specifically. Relevant mediating constructs in this regard include 1) self-relevance, 2) self-identification, 3) emotional attachment, 4) presence, and 5) anthropomorphism (BehmMorawitz, 2013; Jin, 2012; Nowak \& Rauh, 2006; Pessoa et al., 2014; Ratan \& Dawson, 2016; Seo et al., 2017; Song, Kim, Kwon, et al., 2013; Vasalou et al., 2008).

Self-relevance describes "the extent to which the user of a mediated representation that appears and/or behaves like the user is closely connected to the self" (Ratan \& Dawson, 2016, p. 3). Selfidentification refers to "the cognitive connection between an individual and an avatar, with the result being that the individual regards the avatar as a substitute self or has such an illusion" (Suh et al., 2011, p. 715). Both concepts capture how users identify and relate to their digital representation. Importantly, customisability increases self-identification and self-relevance (Bailey et al., 2009; Lim \& Reeves, 2010). In turn, self-identification and self-relevance are found to increase emotional attachment with the avatar (Suh et al., 2011). Also, users pay more attention and feel physically more similar to self-avatars when these avatars reflect them visually as compared to avatars that reflect others (including celebrities, ideal faces, and strangers) (Seo et al., 2017).

Next, emotional attachment describes "an emotion-laden, target-specific bond between a person and a specific object" (Thomson et al., 2005, p. 77). Higher degrees of self-relevance and selfidentification typically yield stronger emotions when interacting with the environment through one's avatar (Ratan \& Dawson, 2016; Ravaja et al., 2006). In addition, users who customised their self-avatar also experience greater emotional attachment to it - which, in turn, increases the avatar's power to affect their behaviour (H.-K. Kim \& Kim, 2016). Emotional attachment with one's avatar also increases perceived presence in the virtual environment, which can be defined as the state in which "users experience their virtual self as if it were their actual self, perhaps even leading to an awareness of themselves inside the virtual environment" (Tamborini \& Skalski, 2006, p. 227). Also, it has been shown that self-avatars can stimulate presence for blind users, helping them to explore environments virtually and identify objects in virtual spaces before visiting the actual site (Cobo et al., 2017).

Anthropomorphism captures how a human-like avatar appears, including naturalness and richness with regards to typical human cues (Nowak \& Rauh, 2006). In the context of selfavatars, it has been shown that this factor increases users' emotional attachment and their perceptions of the avatar's credibility (Nowak \& Rauh, 2006). Evil-looking and corpse-like avatars, on the other hand, affect users' perception of engagement and behaviours negatively when contrasted against heroic and attractive avatars (Peña \& Chen, 2017). 


\section{Interaction with Another Person's Avatar}

\subsection{Avatar Concepts}

In this section, we explore how users interact with other users represented by avatars. Overall, 22 of the reviewed studies $(26.2 \%)$ considered H2A interactions, that is, the direct interaction of a user with another user's avatar. Moreover, 28 studies (33.3\%) considered SA2A interactions, that is, interactions between avatars. The studies are of various contexts such as entertainment (e.g., Dolgov et al., 2014; Dunn \& Guadagno, 2012; Goel et al., 2013; Martens et al., 2018), education (e.g., Ang et al., 2013; Franceschi et al., 2009; H. E. Kim et al., 2017; Lester \& King, 2009; Sutcliffe \& Alrayes, 2012), business (e.g., Hanus \& Fox, 2015; Nowak et al., 2015), health (e.g., Spence et al., 2013), and social interaction (e.g., Jin, 2012; Kohonen-aho \& Tiilikainen, 2017; Wu et al., 2015).

Previous research suggested two marked goal-directed dimensions of avatar design, namely persuasiveness and empathy/emotionality. Persuasive avatars, also referred to as authoritative avatars (Beale \& Creed, 2009), are avatars designed to affect users' choices (Bengtsson et al., 1999; Hanus \& Fox, 2015). One way to achieve persuasiveness is to give users the ability to customise the avatar before the interaction (Hanus \& Fox, 2015). For instance, an avatar may be customised to represent a doctor with high authority in the medical field (Peña et al., 2009). In contrast, the concept of empathic/emotional avatars refers to avatars designed with nonverbal cues and behaviours such as smiling, which can create an emotional connection with users (H.-K. Kim \& Kim, 2016). Felnhofer et al. (2018) found that users interacting with avatars that are controlled by other users reported higher levels of empathy and involvement than users interacting with embodied agents.

\subsection{Influences on User Perceptions and Behaviours}

How an avatar is perceived by its interaction partner(s) is crucial for how it affects their behaviours. First, avatars of high anthropomorphism are perceived as more credible by their interaction partners (Nowak \& Rauh, 2008) and can improve communication (Kang \& Watt, 2013; Khashe et al., 2017). Visually realistic avatars are found to have higher capability of mitigating undesired and facilitating desired behaviours than unrealistic ones (Nowak et al., 2015), e.g., promoting compliance (Khashe et al., 2017). In this vein, Kang \& Watt (2013) found that more visually realistic avatars elicit higher levels of immersion, presence, and trust, which enriches interaction between users and creates more truthful interactions (Hooi \& Cho, 2013; Sutcliffe \& Alrayes, 2012), and increases users' intention to work together to achieve a common goal (Lim \& Reeves, 2010). Ang et al. (2013) found that perceived trust and likeability increase if an avatar exhibits human-like behaviours. Thus, conveyed by perceptions of presence and trust, visually realistic avatars will typically have stronger impacts on user behaviour (Khashe et al., 2017). H. E. Kim et al. (2017) found that avatar-based training can lower anxiety and facilitate interpersonal encounters for patients with social anxiety.

Second, similarity refers to the perceived degree of psychological and/or physiological resemblance between a user and their interaction partner's avatar, including visual appearance, demographic factors, values, beliefs, behaviours, education, training, or knowledge (McCroskey et al., 1975; Nowak \& Rauh, 2006). Higher similarity yields stronger perceptions of group belonging and virtual team identification (Guegan et al., 2017; J. Kim \& Park, 2011; Midha \& Nandedkar, 2012), playing an important role for interaction effectiveness (McCroskey et al., 1975; Webster \& Wong, 2008). Guegan et al. (2017) and Wrzesien et al. (2015) 
also noted that similarity between avatars and users impacts social behaviours and group structuring. Bailenson et al. (2006) pointed out that users tend to find others who are physically and psychologically similar to themselves not only more attractive, but also more persuasive. However, this perception of similarity and presence depends on users' senses of shared context with other users (Kohonen-aho \& Tiilikainen, 2017). Users pay more attention within virtual environments when avatars reflect their own gender (Martens et al., 2018). Users represented by foreign avatars are perceived not similar to them, considered as out-group members, and hence excluded from the group (Schneider et al., 2017). Moreover, the perception of similarity is not limited to gender and physical appearance, but also related to ethnicity and culture. For example, Spence et al. (2013) found that avatars that reflect users' ethnicity are associated with an increased usage intention compared to avatars that do not.

Third, beyond realism and similarity, Leding et al. (2015) showed that avatars with high perceived attractiveness exert strong influences on human behaviour. In this regard, Westerman et al. (2015) found that users are more inclined to interact with physically attractive rather than unattractive avatars. For online social interaction, Bacev-Giles \& Haji (2017) found that users rated avatars as more attractive and likeable if the avatars are perceived to be similar to them. For online advertisements, Keng \& Liu (2013) found that using dynamic, attractive, and 3D (as compared to static, 2D, or unattractive) avatars increase advertisement effectiveness. Moreover, Guadagno et al. (2011) found that a smile can create a sense of connection and increase trust between the interaction partners, enjoyment, and satisfaction. However, when avatars are compared to real human images directly, Balas \& Pacella (2017) found that users rated avatars less trustworthy. Also, people would refuse to share knowledge with a colleague represented by an avatar (Fehrenbacher \& Weisner, 2017). Fabri et al. (2005) found that the use of emotional (as compared to non-emotional) avatars increase user involvement in social communication tasks.

Fourth, users are more likely to be persuaded if an avatar exhibits angry (rather than soft) and/or male (rather than female) voice (Lehto \& Oinas-Kukkonen, 2011). In a recent study (Khashe et al., 2017), it is found that users may be more easily persuaded when a message is communicated by avatars rather than voice or text. In this regard, androgyny refers to "a rating of the avatar's (lack of) masculinity or femininity" (Nowak \& Rauh, 2006, p. 154), affecting several perceptual and behavioural measures. For example, high avatar androgyny is found to reduce the associated user's credibility (Nowak \& Rauh, 2008). Similarly, inappropriately dressed avatars are rated as less anthropomorphic and less credible (Nowak et al., 2015).

Finally, uniqueness indicates that an avatar is different from other digital representations. Uniqueness of avatars, such as unusual physical features, or social or psychological differences, can impair interaction effectiveness (Kang \& Watt, 2013; J. Kim, 2009). J. Kim (2011) stated that users represented by avatars that have visual cues similar to those of their group members perceive a higher level of threat to their uniqueness, compared to those represented by avatars with unique visual cues, leading to lower agreement rates with others.

\section{Interaction with Embodied Agents}

\subsection{Embodied Agent Concepts}

In this section, we focus on embodied agents and their effects on interaction partners. Overall, 19 of the reviewed studies (22.6\%) considered H2EA interactions and 4 (4.8\%) considered SA2EA interactions. The studies are of multiple contexts such as business (e.g., S. Lee \& Choi, 
2017; Nunamaker et al., 2011; Qiu \& Benbasat, 2009), entertainment (e.g., Brave et al. 2005; Mousas et al. 2018; Peña et al. 2016), education (e.g., Ang et al., 2013; Carlotto \& Jaques, 2016), health (e.g., Beege et al., 2017; Jin, 2010; Y. Kim \& Sundar, 2012b), and social interaction (e.g., Dechant et al., 2017; Kang \& Gratch, 2014; Krämer et al., 2013).

The computer as social actors (CASA) paradigm posits that humans apply social rules and norms when interacting with computers (Bailenson \& Blascovich, 2004; Nass et al., 1994). Specifically, visually and behaviourally realistic embodied agents yield higher engagement and involvement between interaction partners (Burgoon et al., 2016; Gerhard et al., 2004). Hence, much of the existing literature on embodied agents is centred on different forms of agent realism, where the differences between human, behavioural, visual, and emotional realism are distinguished. Different design considerations for embodied agents in terms of 1) realism and 2) persuasive and empathic design concepts have also been suggested by previous research.

\subsection{Realism}

First, human realism of embodied agents refers to behavioural, visual, and emotional characteristics (e.g., face and voice) of embodied agents that should be consistent with human characteristics (Mitchell et al., 2011). It represents an important factor for humans as they are more likely to interact with human-like than non-human-like embodied agents (Groom et al., 2009; Parise et al., 1999). In this sense, higher human realism may contribute to a higher degree of faithfulness of the digital representation, as it more closely resembles interpersonal interactions in the real world.

Second, behavioural realism refers to the presence of natural movements, gestures, and reactions of embodied agents (von der Pütten et al., 2010). Manipulation of behavioural realism was found to influence human and avatar responses (Bailenson et al., 2005; Slater et al., 2009), where higher levels of behavioural realism would lead to more likeable and trustworthy embodied agents (Groom et al., 2009). High levels of behavioural realism are usually considered more appropriate in terms of social behaviour and responses (Guadagno et al., 2007; Nass \& Moon, 2000). Embodied agents equipped with realistic motion and physical appearance have greater influence than static or remoted embodied agents, as they stimulate genuine social interactions (Mousas et al., 2018).

Third, visual realism refers to "the degree to which the images of the simulated world are perceived to be real” (C. Lee et al., 2013, p. 548). According to Slater et al. (2009), visual realism has two components. First, geometric realism captures whether the digital representation looks like the real object that it represents. Second, illumination realism refers to the fidelity of lighting (Slater et al., 2009; Strauss, 1990). Notably, visually detailed embodied agents are found to create a sense of social presence (Kwon et al., 2013).

Fourth, emotional realism refers to the expression of emotions similar to that of humans (Beale \& Creed, 2009). Emotion expression entails the ability to establish emphatic relationships between the embodied agents and users (Ahn et al., 2007). In e-learning, for instance, embodied agents with realistic emotional expression can enhance learning experiences and outcomes (Dickey, 2005). As Beale \& Creed (2009) discussed, the importance of emotional consistency in embodied agents and appropriateness to the context could enhance the overall interaction. 


\subsection{Persuasive and Empathic Embodied Agents}

Human-like embodied agents (e.g., a salesperson; Hanus \& Fox, 2015) can be more persuasive when compared to using text or voice in the context of e-commerce (Qiu \& Benbasat, 2010). Importantly, embodied agents that represent human features are likely to be viewed as more authoritative and persuasive by their interaction partners (Qiu \& Benbasat, 2009). For example, Bailenson \& Yee (2005) found that embodied agents with high behavioural realism that mimic user gestures are more persuasive and likeable than agents without this feature. In the context of health, however, Sebastian \& Richards (2017) found that embodied agents representing doctors are not more persuasive than actual medical doctors for mental health patients.

Empathic embodied agents display emotions, which can influence users by increasing likeability and trustworthiness (Brave et al., 2005). For education, Maldonado et al. (2005) found that emotional embodied agents positively enhanced students' performance, experience, and perceptions of the embodied agents' intelligence and credibility. Beege et al. (2017) noted that embodied agents' age is irrelevant when activated alongside with text. Additionally, Bickmore \& Picard (2005) found that embodied agents equipped with a range of non-verbal behaviours (e.g., hand gestures, nod, eye gaze) increase the connection between users and embodied agents, which lead to greater likeability and trust. Importantly, users perceived empathic embodied agents as more caring, sociable, likeable, and trustworthy, and they reported to perceive significantly higher levels of support when an embodied agent created the feeling of an actual partner during the interaction (Brave et al., 2005; S. Lee \& Choi, 2017).

\subsection{The Uncanny Valley}

While human realism is important, all too realistic embodied agents bear the risk of making people feel uncomfortable and often result in negative reactions (Burgoon et al., 2016; Mara \& Appel, 2015). This effect is known as the "uncanny valley", which, according to MacDorman \& Ishiguro (2006) and Mori (1970), refers to human-like digital representations that appear almost, but not exactly like real human beings and consequently stimulate feelings of eeriness and revulsion. Since people usually know that the displayed entity is artificial (regardless of whether representing a human or not), and not a video stream of an actual human being, interaction design should keep a safe distance from realism in order to avoid the uncanny valley effect. In this sense, designers may employ a stylised or "comicified" representation with empathic features (Teubner, Adam, Camacho, \& Hassanein, 2014).

It is also essential to ensure a balance between appearance and behaviour of embodied agents to avoid the uncanny valley effect (Allbeck \& Badler, 2004; Groom et al., 2009; Mitchell et al., 2011). On one hand, users dislike embodied agents that are too realistic (e.g., human replica; Groom et al., 2009) and exhibit negative responses to unrealistic (non-human-like) embodied agents such as zombies (Mousas et al., 2018). On the other hand, people experience lower levels of satisfaction when communicating with a less realistic (e.g., animalistic) digital representation. Hence, designers should include characteristics that increase relatedness, feelings of being understood, attractiveness, empathy, and so forth that appear natural to users to avoid the feeling of eeriness. Interacting with embodied agents that do not reflect users' ethnicity is rated as less trustworthy compared to interacting with embodied agents that do (Tamborini et al., 2018). 
It is worth noting that this eeriness is not only about human-like physical appearances of embodied agents, but also about the display of emotion states. The design of embodied agents should focus not only on human-like appearance and behaviour, but also on emotions displayed by embodied agents (Beale \& Creed, 2009; Saygin, 2011). An embodied agent that smiles with a concerned voice is suggested to be problematic, as it exhibits inconsistency in audio-visual realism (Beale \& Creed, 2009), which may in turn reduce users' perceived faithfulness of the digital representation. Designers should, therefore, consider contextual appropriateness to embodied agent emotional displays to avoid the uncanny valley effect.

\section{Discussion and Conclusion}

\subsection{Summary of Findings}

Over the past twenty years, researchers from the IS domain have conducted controlled experiments in laboratory and field environments to better understand the interactions of human users with digital visual representations of humans (avatars) and computer agents (embodied agents). To stimulate research that extends the knowledge of avatars and embodied agents, and potentially enables innovative applications of such digital representations, we conducted the present SLR. Based on this review, we provided a comprehensive overview of the extant literature on experimental research on avatars and embodied agents and identified key aspects that affect human perceptions and behaviours when interacting with avatars or embodied agents. Table 4 provides a summary of our findings.

\begin{tabular}{|c|c|c|c|c|}
\hline \begin{tabular}{|c|} 
Interaction \\
Types \\
\end{tabular} & \begin{tabular}{c|c|} 
Design \\
Considerations
\end{tabular} & $\begin{array}{l}\text { Psychological } \\
\text { Constructs }\end{array}$ & $\begin{array}{c}\text { Examples of Implications } \\
\text { of Design Choices }\end{array}$ & $\begin{array}{c}\text { Examples of Interaction } \\
\text { Outcomes } \\
\end{array}$ \\
\hline \multirow{2}{*}{ H2SA } & \multirow{2}{*}{$\begin{array}{l}\text { Customisation, } \\
\text { Proteus effect }\end{array}$} & Similarity & $\begin{array}{l}\text { Users feel more self-relevance and } \\
\text { similar to their avatars if they can } \\
\text { customise them }\end{array}$ & $\begin{array}{l}\text { Positive effects on helping } \\
\text { behaviour (e.g., Dolgov et } \\
\text { al., 2014) }\end{array}$ \\
\hline & & Presence & $\begin{array}{l}\text { Users feel more socially present } \\
\text { using their self-avatars }\end{array}$ & $\begin{array}{l}\text { Increased emotional } \\
\text { attachment to avatars (e.g., } \\
\text { H.-K. Kim \& Kim, 2016) }\end{array}$ \\
\hline \multirow{4}{*}{$\begin{array}{l}\mathrm{H} 2 \mathrm{~A} / \\
\mathrm{SA} 2 \mathrm{~A}\end{array}$} & \multirow{4}{*}{$\begin{array}{l}\text { Customisation, } \\
\text { Realism, } \\
\text { Proteus effect }\end{array}$} & Similarity & $\begin{array}{l}\text { Users feel similar to customised } \\
\text { avatars that resemble them in terms } \\
\text { of gender, physical appearance, and } \\
\text { ethnicity }\end{array}$ & $\begin{array}{l}\text { Increased sense of group } \\
\text { belonging (e.g., Guegan et } \\
\text { al., 2017) }\end{array}$ \\
\hline & & Attractiveness & $\begin{array}{l}\text { Users prefer to interact with or use } \\
\text { attractive avatars }\end{array}$ & $\begin{array}{l}\text { Reduced risk-taking } \\
\text { behaviour } \\
\text { (e.g., H.-K. Kim \& Kim, } \\
\text { 2016) }\end{array}$ \\
\hline & & Anthropomorphism & $\begin{array}{l}\text { Users prefer to interact with more } \\
\text { human-like avatars in terms of } \\
\text { visual, behavioural, and emotional } \\
\text { realism }\end{array}$ & $\begin{array}{l}\text { Perceptions of higher } \\
\text { naturalness in interaction } \\
\text { (e.g., Garau et al., 2003) }\end{array}$ \\
\hline & & Presence & $\begin{array}{l}\text { Users feel more socially present in } \\
\text { the interaction with human-like } \\
\text { avatars }\end{array}$ & $\begin{array}{l}\text { Higher degrees of } \\
\text { immersion } \\
\text { (e.g., Franceschi et al., 2009) }\end{array}$ \\
\hline
\end{tabular}




\begin{tabular}{|c|c|c|c|c|}
\hline \begin{tabular}{|c|}
$\begin{array}{c}\text { Interaction } \\
\text { Types }\end{array}$ \\
\end{tabular} & $\begin{array}{c}\text { Design } \\
\text { Considerations }\end{array}$ & $\begin{array}{c}\text { Psychological } \\
\text { Constructs } \\
\end{array}$ & $\begin{array}{c}\text { Examples of Implications } \\
\text { of Design Choices }\end{array}$ & $\begin{array}{c}\text { Examples of Interaction } \\
\text { Outcomes } \\
\end{array}$ \\
\hline \multirow{4}{*}{$\begin{array}{l}\text { H2EA / } \\
\text { SA2EA }\end{array}$} & \multirow{4}{*}{$\begin{array}{l}\text { Realism, } \\
\text { Uncanny } \\
\text { valley }\end{array}$} & Anthropomorphism & $\begin{array}{l}\text { Users prefer adequately realistic and } \\
\text { human-like embodied agents that } \\
\text { exhibit consistency in terms of } \\
\text { visual, behavioural, and emotional } \\
\text { realisms (human-like realisms) }\end{array}$ & $\begin{array}{l}\text { Irritation and } \\
\text { disengagement for too low } \\
\text { (e.g., Mousas et al., 2018) or } \\
\text { too high (e.g., MacDorman } \\
\text { et al., 2009) levels of } \\
\text { anthropomorphism }\end{array}$ \\
\hline & & Enjoyment & $\begin{array}{l}\text { Users perceive interactions with } \\
\text { embodied agents as less enjoyable if } \\
\text { these exhibit inconsistency in terms } \\
\text { of visual, behavioural, and } \\
\text { emotional realisms }\end{array}$ & $\begin{array}{l}\text { Disengagement from the } \\
\text { interaction if not enjoyable } \\
\text { (e.g., Groom et al., 2009) }\end{array}$ \\
\hline & & Similarity & $\begin{array}{l}\text { Users prefer to interact with } \\
\text { embodied agents that are similar to } \\
\text { them (e.g., in terms of gender, } \\
\text { appearance, or ethnicity) }\end{array}$ & $\begin{array}{l}\text { Higher involvement and } \\
\text { trust in the embodied agent } \\
\text { (e.g., Tamborini et al., 2018) }\end{array}$ \\
\hline & & Presence & $\begin{array}{l}\text { Users prefer to interact with human- } \\
\text { like embodied agents }\end{array}$ & $\begin{array}{l}\text { Higher levels of liking and } \\
\text { credibility as a source of } \\
\text { information (e.g., Y. Kim \& } \\
\text { Sundar, 2012a) }\end{array}$ \\
\hline
\end{tabular}

Table 4. Summary of findings from the SLR

In the context of human interaction with self-avatars (H2SA), experiments have shown that when people are given the freedom to customise their avatar, it would not necessarily reflect their actual selves (Vasalou \& Joinson, 2009). Customisation enables users to create a sense of relevance with their avatars, which, in turn, can increase identification with the self-avatar. Notably, if there is a strong sense of self-relevance, this may affect the user's behaviour positively or negatively (Proteus effect) (Fox et al., 2013). Emotional attachment with the selfavatar is an important aspect of the digital representation if the purpose of interaction is to change user behaviour. Perceived similarity and customisation of digital representations lead to emotional attachment with avatars (H.-K. Kim \& Kim, 2016) and higher levels of selfpresence (Seo et al., 2017). Basically, customisation should be available to facilitate behavioural change, as users would customise their avatars to their liking.

In the context of human and self-avatar interaction with another person's avatar (H2A and SA2A), the user or self-avatar interacts with another person's avatar to achieve a common goal. Research has shown that avatar representations affect the interaction partners' perceptions via the construct of anthropomorphism. Garau et al. (2003) found that interactions with realistic avatars, in terms of visual (human-like) and behavioural realisms (consistent with human behaviours), are considered as more natural (i.e., to feel more like a face-to-face interaction). Attractiveness of digital representations influences the interaction partners' behaviours in terms of risk taking (H.-K. Kim \& Kim, 2016). Psychological similarity emphasises the importance for the avatar to be part of a team (Guegan et al., 2017), which means that the avatar's customisation should be consistent, so it can be identified as part of the team or group. Uniqueness and similarity are two important constructs for ensuring that an avatar can be identified by the interaction partners. Immersion and presence, which work interchangeably, are important for H2A and SA2A interactions too. That is, presence increases immersion and vice versa. Presence is magnified by the fact the interaction partners can see and hear each other (Franceschi et al., 2009), which attracts user attention. Interacting with avatars can result 
in behavioural change due to the Proteus effect, which affects users' behaviours either by acting similarly or differently to other avatars in the interaction.

In the context of human and self-avatar interaction with an embodied agent (H2EA and SA2EA), research showed that human realism in an embodied agent should reflect natural human behaviour, appearance, and emotion. It is important to ensure that all human realism dimensions are matched with actual human behaviour, emotion, and visual cues in order to avoid the uncanny valley effect (Groom et al., 2009), which means that unmatched human realism can irritate people and lead to disengagement (Mitchell et al., 2011). Human realism is an important aspect of embodied agents' representation, to create a digital representation that has human-like features and also to create a sense of social cues in the interaction. This is because humans usually prefer to digitally interact with a representation that is similar to them. The perception of similarity here is not limited to physical appearance or gender between users and digital representations, but also includes ethnicity and culture (Tamborini et al., 2018). Human realism and psychological similarity can increase the sense of presence, immersion, and involvement with the embodied agent. These, in turn, will ensure enjoyment, information credibility, likeability, and trust between the interaction partners. Similarly, information provided by an embodied agent is more credible and believable if it exhibits human-like features (Kim \& Sundar, 2012a), and if these features are consistent with actual human features. Expectedly, likeability of embodied agents hinges on matching human features realistically. In summary, human realism can induce trust (Riedl et al., 2014), which enables the interaction partners to share information or work collectively with the embodied agent.

To summarise, appearance and behaviour of avatars and embodied agents are important antecedents of interaction outcomes and may lead to negative (e.g., disengagement and untrustworthiness) or positive (e.g., enjoyment) user reactions. According to Guadagno et al. (2007), the more anthropomorphic an embodied agent or avatar appears, the more realistic its interactional behaviour such as facial expressions or smiles needs to be for the digital representation to stimulate appropriate social/behavioural responses. Hence, in line with RT (Burton-Jones et al., 2017; Recker et al., 2019), avatars and embodied agents may yield higher faithfulness (e.g., in terms of credibility, similarity, presence) if these representations closely resemble the real-world phenomena of human cues in interpersonal interactions (e.g., Groom et al., 2009; Nowak \& Rauh, 2006). In contrast, less anthropomorphic representations, that is, with inconsistencies in behavioural, emotional, and visual realism, may lead to adverse outcomes in the interaction between humans and digital representations.

\subsection{Practical Implications}

Most digital interactions of avatars and embodied agents focus on stimulating changes in user experience (e.g., emotion) and facilitating targeted behaviours. Based on the present literature review, we have identified six factors designers should particularly take into account when considering the design and implementation of avatars and embodied agents in practice.

First, designers should be aware of the Proteus effect, which relates an avatar's characteristics to its "owner's" own behaviour (Fox et al., 2013; Peña et al., 2009, 2016; Yee and Bailenson, 2007). The Proteus effect occurs when users are represented by avatars in a virtual environment (Yee et al., 2009). It can have positive implications when there is a need to change certain behaviours or perceptions. In this sense, a positive appearance of avatars can increase user confidence - especially in conversations or negotiation tasks (Won et al., 2015; Yee \& 
Bailenson, 2007). Expectedly, a negative connotation (e.g., overweight avatars) can dampen user motivation and mood by reinforcing unhelpful judgment, while an athletic avatar may promote liveliness and boost physical activity (Peña \& Kim, 2014). It is hence important for designers to carefully take into account the Proteus effect, as their virtual designs may have unimagined or undesired consequences in the physical world (H.-K. Kim \& Kim, 2016).

Second, designers need to consider the uncanny valley effect, which occurs when the appearance of a representation looks almost like a real human, but just not fully so (Beale \& Creed, 2009; Tinwell et al., 2011). Since virtually all avatar designs will not achieve full human realism, designers should - despite their efforts to embed human and social cues such as facial features and gestures - keep a safe distance from all too realistic avatars. In this sense, a deliberate abstraction and stylisation, for instance, using comic faces, may be a viable option. Moreover, they should employ attractive and empathetic avatars to reduce uncanny impulses.

Third, designers need to consider the concept of presence for the design of digital interaction, as this does not represent the natural form of communication among humans. Designers should focus on features that stimulate presence to make the interaction appear social. Previous research has shown that digital representations that exhibit consistent behavioural realism yield greater social influence (Kang \& Gratch, 2014). Importantly, digital representations that are similar to users are perceived as more sociable, enjoyable, and useful to interact with than dissimilar ones (Bacev-Giles \& Haji, 2017; Qiu \& Benbasat, 2010; Seo et al., 2017). Designers should be aware of this to stimulate presence.

Fourth, persuasive design of digital representations is used to influence users' behaviours or decisions towards a specific idea. Research has shown that users prefer to interact with powerful and authoritative avatars, which can achieve better outcomes (Fox et al., 2013; Schultze, 2011). Also, digital representations with strong facial expressions increase persuasiveness. Hence, for behaviour change, more engaged avatars are preferable over passive ones (Hyde et al., 2015). Moreover, persuasion can be supported by higher anthropomorphism (e.g., using detailed facial expressions). Overall, more visually realistic avatars convey stronger messages, increase the chances to persuade users (Khashe et al., 2017) and, in turn, guide behaviour (Aljaroodi, Adam, Chiong, Cornforth, \& Minichiello, 2017; Noorbergen et al., 2019).

Fifth, designers should consider empathic elements in designing digital representations. Empathy creates a sense of social interaction for the interaction partners. Experiments with digital representations have shown that a simple display of emotion can change the result of an interaction. Importantly, users dislike embodied agents that display inconsistent emotions (Beale \& Creed, 2009) and exhibit negative responses to agents with pale and gaunt appearances (Mousas et al., 2018). Additionally, empathic elements should be appropriately matched with human emotions and their transitions (Burgoon et al., 2016). Empathic elements are important aspects of designing digital representations, because they make the interaction more supportive, enjoyable, trusting, and open for the users (Guadagno et al., 2011). Empathy leads to more positive interactions, including greater likeability and trustworthiness between the interaction partners (Brave et al., 2005). Designers should consider including characteristics of non-verbal and verbal behaviour to increase emotional attachment (Beale \& Creed, 2009).

Lastly, designers should ensure that customisability is available to users, as it enhances the connection between users and their digital representations (Hanus \& Fox, 2015; Ratan \& Sah, 2015). Enabling users to create their own avatars would make the users more carefully engaged 
in preventative (e.g., quitting unhealthy habits) or proactive behaviour (e.g., picking up healthy routines) (Y. Kim \& Sundar, 2012b). Customisation is used to change or enhance the user's behaviour and try to elevate the user's level of emotional attachment (Ducheneaut et al., 2009; Hanus \& Fox, 2015). Therefore, designers should ensure that digital representations can be customised by the users to create a stronger emotional connection.

\subsection{Future Research Directions}

Building on the findings of our literature review, we have identified three major directions for future IS research on avatars and embodied agents. First, in terms of research methodology, it needs to be noted that the majority of reviewed studies were exclusively conducted experiments in laboratory settings (84 out of 90 studies) and only six studies considered a field setting (e.g., Barata et al., 2017; Rodrigues et al., 2016; Sanchez-Valdes \& Trivino, 2015). There is limited knowledge as to how critical the real-world context is for transferring results of laboratory studies to the field. This can be addressed in future research by putting a stronger emphasis on field experiments. Further, so far only eight studies considered physiological measurements (e.g., see Lim \& Reeves, 2010). However, it is known that human emotional responses involve unconscious processes (Walla \& Panksepp, 2013). Hence, there is a need for more physiological studies to uncover the unconscious effects of digital representations on users and their links to user perceptions. It is also necessary to note that our review has focused exclusively on experimental research. There is thus a need for future research to discern whether the results presented here are intrinsic to experimental studies. This can be achieved through a complementary review that focuses on other (non-experimental) research methods or through multi-method approaches that combine experimental and non-experimental approaches (e.g., focus groups, interviews).

Second, our review has identified several interesting knowledge gaps in terms of avatar appearance. So far, studies on self-avatars have exclusively focused on face-only or full-body avatars (see Table 2). It would be interesting to investigate half-body avatars in the self-avatar context and contrast it to the results of face-only and full-body avatars. Further, while research has emphasised the importance of high similarity between the user and a digital representation, the majority of studies on similarity considered just the avatar's physical appearance (e.g., body size, clothing, hair) or gender. Only three studies have explicitly considered the user's ethnicity (Fehrenbacher \& Weisner, 2017; Spence et al., 2013; Tamborini et al., 2018). Digital representations in these three studies were based on, and hence represented, the ethnicity of (1) African-American and Caucasian people (Spence et al., 2013; Tamborini et al., 2018), and (2) Asian and Caucasian people (Fehrenbacher \& Weisner, 2017). It is known that visual appearances that are appropriate for one culture can be inappropriate in another (Abdallah \& Douglas, 2010; Aljaroodi, Chiong, \& Adam, 2017; Yusof \& Zakaria, 2007). Therefore, further research is needed to explore the effects of similarity and other constructs (e.g., credibility, likeability) in the context of users' culture and ethnicity. Also, the scope should be broadened beyond Asian, African-American, and Caucasian cultures (e.g., Arabian and Indigenous cultures).

Third, the degree of overlap in the psychological constructs investigated by the different studies is quite low, even within the five interaction types (see Figure 2). While presence and similarity emerge as the most widely-used constructs, other constructs such as attractiveness, enjoyment, and likeability have only been investigated by about $10 \%$ of the studies. Also, there is no study that has explored the 11 constructs listed in Table 1 simultaneously. There is thus 
a lack of understanding of the interrelationships between them (e.g., credibility, likeability, enjoyment, and similarity), and how these relationships between constructs may be dependent on whether the user is interacting with an avatar or an embodied agent.

\subsection{Concluding Remarks}

Our study has provided a concise overview of the different digital representations investigated in experimental IS research, including avatars and embodied agents. The degree of anthropomorphism represents a pivotal lever for designers of digital user representations. Notably, digital representations can affect people in manifold ways, including the Proteus and uncanny valley effects. We hope that researchers and practitioners will find this systematic review useful as a reference for experimental research on avatars and embodied agents to inform implementations of digital user representations in practice.

\section{References}

Abdallah, S., \& Douglas, J. (2010). Students' first impression of Second Life: A case from the United Arab Emirates. Turkish Online Journal of Distance Education, 11(3), 183-192.

ABS. (2015). Academic journal guide 2015. Association of Business Schools (ABS).

ACPHIS. (2013). Recommended IS conferences. Australian Council of Professors and Heads of Information Systems (ACPHIS).

Ahn, H., Teeters, A., Wang, A., Breazeal, C., \& Picard, R. (2007). Stoop to conquer: Posture and affect interact to influence computer users' persistence. In 2nd International Conference on Affective Computing and Intelligent Interaction (pp. 582-593). Heidelberg, Germany.

Aljaroodi, H. M., Adam, M. T. P., Chiong, R., Cornforth, D. J., \& Minichiello, M. (2017). Empathic avatars in stroke rehabilitation: A co-designed mHealth artifact for stroke survivors. In DESRIST Proceedings (pp. 73-89). Karlsruhe, Germany.

Aljaroodi, H. M., Chiong, R., \& Adam, M. T. P. (2017). Designing persuasive avatars in mHealth for Arabic culture: A qualitative study. In ACIS Proceedings (pp. 1-10). Hobart, Australia.

Allbeck, J. M., \& Badler, N. I. (2004). Representing and parameterizing agent behaviors. In Life-Like Characters (pp. 19-38). Heidelberg, Germany.

Ang, C. S., Bobrowicz, A., Siriaraya, P., Trickey, J., \& Winspear, K. (2013). Effects of gesturebased avatar-mediated communication on brainstorming and negotiation tasks among younger users. Computers in Human Behavior, 29(3), 1204-1211.

Bacev-Giles, C., \& Haji, R. (2017). Online first impressions: Person perception in social media profiles. Computers in Human Behavior, 75, 50-57.

Bailenson, J. N., \& Blascovich, J. (2004). Avatars. In Encyclopedia of Human-Computer Interaction (pp. 64-68.). Massachusetts, United States: Berkshire Publishing Group.

Bailenson, J. N., Garland, P., Iyengar, S., \& Yee, N. (2006). Transformed facial similarity as a political cue: A preliminary investigation. Political Psychology, 27(3), 373-385.

Bailenson, J. N., Swinth, K., Hoyt, C., Persky, S., Dimov, A., \& Blascovich, J. (2005). The independent and interactive effects of embodied-agent appearance and behavior on selfreport, cognitive, and behavioral markers of copresence in immersive virtual environments. Presence, 14(4), 379-393. 
Bailenson, J. N., \& Yee, N. (2005). Digital chameleons: Automatic assimilation of nonverbal gestures in immersive virtual environments. Psychological Science, 16(10), 814-819.

Bailey, R., Wise, K., \& Bolls, P. (2009). How avatar customizability affects children's arousal and subjective presence during junk food-sponsored online video games. CyberPsychology \& Behavior, 12(3), 277-283.

Balas, B., \& Pacella, J. (2017). Trustworthiness perception is disrupted in artificial faces. Computers in Human Behavior, 77, 240-248.

Barata, G., Gama, S., Jorge, J., \& Gonçalves, D. (2017). Studying student differentiation in gamified education: A long-term study. Computers in Human Behavior, 71, 550-585.

Beale, R., \& Creed, C. (2009). Affective interaction: How emotional agents affect users. International Journal of Human-Computer Studies, 67(9), 755-776.

Beege, M., Schneider, S., Nebel, S., Mittangk, J., \& Rey, G. D. (2017). Ageism - Age coherence within learning material fosters learning. Computers in Human Behavior, 75, 510-519.

Behm-Morawitz, E. (2013). Mirrored selves: The influence of self-presence in a virtual world on health, appearance, and well-being. Computers in Human Behavior, 29(1), 119-128.

Bengtsson, B., Burgoon, J. K., Cederberg, C., Bonito, J., \& Lundeberg, M. (1999). The impact of anthropomorphic interfaces on influence understanding, and credibility. In HICSS Proceedings (pp. 1-15). Maui: United States.

Bickmore, T. W., \& Picard, R. W. (2005). Establishing and maintaining long-term humancomputer relationships. ACM Transactions on Computer-Human Interaction, 12(2), 293327.

Brave, S., Nass, C., \& Hutchinson, K. (2005). Computers that care: Investigating the effects of orientation of emotion exhibited by an embodied computer agent. International Journal of Human-Computer Studies, 62(2), 161-178.

Burgoon, J. K., Bonito, J. A., Lowry, P. B., Humpherys, S. L., Moody, G. D., Gaskin, J. E., \& Giboney, J. S. (2016). Application of expectancy violations theory to communication with and judgments about embodied agents during a decision-making task. International Journal of Human-Computer Studies, 91, 24-36.

Burton-Jones, A., Recker, J., Indulska, M., Green, P., \& Weber, R. (2017). Assessing representation theory with a framework for pursuing success and failure. MIS Quarterly, 41(4), 1307-1333.

Carlotto, T., \& Jaques, P. A. (2016). The effects of animated pedagogical agents in an Englishas-a-foreign-language learning environment. International Journal of Human-Computer Studies, 95, 15-26.

Carter, M., Allison, F., Downs, J., \& Gibbs, M. (2015). Player identity dissonance and voice interaction in games. In Proceedings of the 2015 Annual Symposium on Computer-Human Interaction in Play (pp. 265-269). London, United Kingdom.

Cobo, A., Guerron, N. E., Martín, C., del Pozo, F., \& Serrano, J. J. (2017). Differences between blind people's cognitive maps after proximity and distant exploration of virtual environments. Computers in Human Behavior, 77, 294-308. 
Davis, A., Khazanchi, D., Murphy, J., Zigurs, I., \& Owens, D. (2009). Avatars, people, and virtual worlds: Foundations for research in metaverses. Journal of the Association for Information Systems, 10(2), 90-117.

Dechant, M., Trimpl, S., Wolff, C., Mühlberger, A., \& Shiban, Y. (2017). Potential of virtual reality as a diagnostic tool for social anxiety: A pilot study. Computers in Human Behavior, $76,128-134$.

Dickey, M. D. (2005). Three-dimensional virtual worlds and distance learning: Two case studies of active worlds as a medium for distance education. British Journal of Educational Technology, 36(3), 439-451.

Dolgov, I., Graves, W. J., Nearents, M. R., Schwark, J. D., \& Brooks Volkman, C. (2014). Effects of cooperative gaming and avatar customization on subsequent spontaneous helping behavior. Computers in Human Behavior, 33, 49-55.

Ducheneaut, N., Wen, M. H., Yee, N., \& Wadley, G. (2009). Body and mind: A study of avatar personalization in three virtual worlds. In The SIGCHI Conference on Human Factors in Computing Systems (pp. 1151-1160). Boston, United States.

Dunn, R. A., \& Guadagno, R. E. (2012). My avatar and me - Gender and personality predictors of avatar-self discrepancy. Computers in Human Behavior, 28(1), 97-106.

Fabri, M., Moore, D. J., \& Hobbs, D. J. (2005). Empathy and enjoyment in instant messaging. In Mckinnon, L., Bertlesen, O., Bryan-Kinns, N. (Eds.), Proceedings of 19th British HCI Group Annual Conference (HCI2005) (pp. 4-9). Edinburgh, United Kingdom

Fehrenbacher, D. D., \& Weisner, M. M. (2017). Avatars and knowledge sharing. In ICIS Proceedings (pp. 1-18). Seoul, South Korea.

Felnhofer, A., Kafka, J. X., Hlavacs, H., Beutl, L., Kryspin-Exner, I., \& Kothgassner, O. D. (2018). Meeting others virtually in a day-to-day setting: Investigating social avoidance and prosocial behavior towards avatars and agents. Computers in Human Behavior, 80, 399406.

Felnhofer, A., Kothgassner, O. D., Hauk, N., Beutl, L., Hlavacs, H., \& Kryspin-Exner, I. (2014). Physical and social presence in collaborative virtual environments: Exploring age and gender differences with respect to empathy. Computers in Human Behavior, 31(1), 272279.

Fox, J., \& Ahn, S. J. (2012). Avatars: Portraying, Exploring, and Changing Online and Offline Identities. In R., Luppicini (Ed.), Handbook of Research on Technoself: Identity in a Technological Society (pp. 225-271). Pennsylvania, United States: IGI Global.

Fox, J., Ahn, S. J. (Grace), Janssen, J. H., Yeykelis, L., Segovia, K. Y., \& Bailenson, J. N. (2015). Avatars versus agents: A meta-analysis quantifying the effect of agency on social influence. Human-Computer Interaction, 30(5), 401-432.

Fox, J., Bailenson, J. N., \& Tricase, L. (2013). The embodiment of sexualized virtual selves: The Proteus effect and experiences of self-objectification via avatars. Computers in Human Behavior, 29(3), 930-938.

Franceschi, K., Lee, R. M., Zanakis, S. H., \& Hinds, D. (2009). Engaging group e-learning in virtual worlds. Journal of Management Information Systems, 26(1), 73-100. 
Galanxhi, H., \& Nah, F. F. H. (2007). Deception in cyberspace: A comparison of text-only vs. avatar-supported medium. International Journal of Human-Computer Studies, 65(9), 770783.

Garau, M., Slater, M., Vinayagamoorthy, V., Brogni, A., Steed, A., \& Sasse, M. A. (2003). The impact of avatar realism and eye gaze control on perceived quality of communication in a shared immersive virtual environment. In The SIGCHI Conference on Human Factors in Computing Systems (pp. 529-536). Fort Lauderdale, United States.

Gerhard, M., Moore, D., \& Hobbs, D. (2004). Embodiment and copresence in collaborative interfaces. International Journal of Human-Computer Studies, 61(4), 453-480.

Goel, L., Johnson, N., Junglas, I., \& Ives, B. (2013). Predicting users' return to virtual worlds: A social perspective. Information Systems Journal, 23(1), 35-63.

Gong, L. (2007). Is happy better than sad even if they are both non-adaptive? Effects of emotional expressions of talking-head interface agents. International Journal of HumanComputer Studies, 65(3), 183-191.

Greenwood, D. N. (2008). Television as escape from self: Psychological predictors of media involvement. Personality and Individual Differences, 44(2), 414-424.

Grinberg, A. M., Careaga, J. S., Mehl, M. R., \& O'Connor, M. F. (2014). Social engagement and user immersion in a socially based virtual world. Computers in Human Behavior, 36, 479486.

Groom, V., Nass, C., Chen, T., Nielsen, A., Scarborough, J. K., \& Robles, E. (2009). Evaluating the effects of behavioral realism in embodied agents. International Journal of HumanComputer Studies, 67(10), 842-849.

Grudin, J. (2001). Desituating action: Digital representation of context. Human-Computer Interaction, 16(2), 269-286.

Guadagno, R. E., Blascovich, J., Bailenson, J. N., \& Mccall, C. (2007). Virtual humans and persuasion: The effects of agency and behavioral realism. Media Psychology, 10(1), 1-22.

Guadagno, R. E., Swinth, K. R., \& Blascovich, J. (2011). Social evaluations of embodied agents and avatars. Computers in Human Behavior, 27(6), 2380-2385.

Guegan, J., Buisine, S., Mantelet, F., Maranzana, N., \& Segonds, F. (2016). Avatar-mediated creativity: When embodying inventors makes engineers more creative. Computers in Human Behavior, 61, 165-175.

Guegan, J., Segonds, F., Barre, J., Maranzana, N., Mantelet, F., \& Buisine, S. (2017). Social identity cues to improve creativity and identification in face-to-face and virtual groups. Computers in Human Behavior, 77, 140-147.

Hämäläinen, R., Oksanen, K., \& Häkkinen, P. (2008). Designing and analyzing collaboration in a scripted game for vocational education. Computers in Human Behavior, 24(6), 24962506.

Hammick, J. K., \& Lee, M. J. (2014). Do shy people feel less communication apprehension online? The effects of virtual reality on the relationship between personality characteristics and communication outcomes. Computers in Human Behavior, 33, 302-310. 
Hanus, M. D., \& Fox, J. (2015). Persuasive avatars: The effects of customizing a virtual salespersons appearance on brand liking and purchase intentions. International Journal of Human-Computer Studies, 84, 33-40.

Heeter, C. (1992). Being there: The subjective experience of presence. Presence: Teleoperators $\mathcal{E}$ Virtual Environments, 1(2), 262-271.

Heidig, S., \& Clarebout, G. (2011). Do pedagogical agents make a difference to student motivation and learning? Educational Research Review, 6(1), 27-54.

Hofer, M., Hüsser, A., \& Prabhu, S. (2017). The effect of an avatar's emotional expressions on players' fear reactions: The mediating role of embodiment. Computers in Human Behavior, $75,883-890$.

Hooi, R., \& Cho, H. (2013). Deception in avatar-mediated virtual environment. Computers in Human Behavior, 29(1), 276-284.

Huang, R., Kahai, S., \& Jestice, R. (2010). The contingent effects of leadership on team collaboration in virtual teams. Computers in Human Behavior, 26(5), 1098-1110.

Hyde, J., Carter, E. J., Kiesler, S., \& Hodgins, J. K. (2015). Using an interactive avatar's facial expressiveness to increase persuasiveness and socialness. In The 33rd Annual ACM Conference on Human Factors in Computing Systems (pp. 1719-1728). Seoul, South Korea.

IFIP. (2015). IFIP TC8 ranking of IS conferences. International Federation for Information Processing: Technical Committee 8 (IFIP: TC8).

Jin, S.-A. A. (2010). The effects of incorporating a virtual agent in a computer-aided test designed for stress management education: The mediating role of enjoyment. Computers in Human Behavior, 26(3), 443-451.

Jin, S.-A. A. (2012). The virtual malleable self and the virtual identity discrepancy model: Investigative frameworks for virtual possible selves and others in avatar-based identity construction and social interaction. Computers in Human Behavior, 28(6), 2160-2168.

Kang, S. H., \& Gratch, J. (2014). Exploring users' social responses to computer counseling interviewers' behavior. Computers in Human Behavior, 34, 120-130.

Kang, S. H., \& Watt, J. H. (2013). The impact of avatar realism and anonymity on effective communication via mobile devices. Computers in Human Behavior, 29(3), 1169-1181.

Kaye, L. K., Pennington, C. R., \& McCann, J. J. (2018). Do casual gaming environments evoke stereotype threat? Examining the effects of explicit priming and avatar gender. Computers in Human Behavior, 78, 142-150.

Keng, C. J., \& Liu, C. C. (2013). Can avatar and self-referencing really increase the effects of online 2-D and 3-D advertising? Computers in Human Behavior, 29(3), 791-802.

Khashe, S., Lucas, G., Becerik-Gerber, B., \& Gratch, J. (2017). Buildings with persona: Towards effective building-occupant communication. Computers in Human Behavior, 75, 607-618.

Kim, H.-K., \& Kim, S.-H. (2016). Understanding emotional bond between the creator and the avatar: Change in behavioral intentions to engage in alcohol-related traffic risk behaviors. Computers in Human Behavior, 62, 186-200. 
Kim, H. E., Hong, Y., Kim, M., Jung, Y. H., Kyeong, S., \& Kim, J.-J. (2017). Effectiveness of selftraining using the mobile-based virtual reality program in patients with social anxiety disorder. Computers in Human Behavior, 73, 614-619.

Kim, J. (2009). "I want to be different from others in cyberspace" The role of visual similarity in virtual group identity. Computers in Human Behavior, 25(1), 88-95.

Kim, J. (2011). Two routes leading to conformity intention in computer-mediated groups: Matching versus mismatching virtual representations. Journal of Computer-Mediated Communication, 16(2), 271-287.

Kim, J., \& Park, H. S. (2011). The effect of uniform virtual appearance on conformity intention: Social identity model of deindividuation effects and optimal distinctiveness theory. Computers in Human Behavior, 27(3), 1223-1230.

Kim, Y., \& Sundar, S. S. (2012a). Anthropomorphism of computers: Is it mindful or mindless? Computers in Human Behavior, 28(1), 241-250.

Kim, Y., \& Sundar, S. S. (2012b). Visualizing ideal self vs. actual self through avatars: Impact on preventive health outcomes. Computers in Human Behavior, 28(4), 1356-1364.

Kitchenham, B., \& Charters, S. (2007). Guidelines for performing systematic literature reviews in software engineering. Technical Report EBSE.

Kohonen-aho, L., \& Tiilikainen, S. (2017). Constructing shared context for temporary teams in virtual worlds with informal interaction. In ICIS Proceedings (pp. 1-19). Seoul, South Korea.

Koles, B., \& Nagy, P. (2012). Virtual customers behind avatars: The relationship between virtual identity and virtual consumption in second life. Journal of Theoretical and Applied Electronic Commerce Research, 7(2), 87-105.

Kothgassner, O. D., Griesinger, M., Kettner, K., Wayan, K., Volkl-Kernstock, S., Hlavacs, H., Beutl, L., Felnhofer, A. (2017). Real-life prosocial behavior decreases after being socially excluded by avatars, not agents. Computers in Human Behavior, 70, 261-269.

Krämer, N., Kopp, S., Becker-Asano, C., \& Sommer, N. (2013). Smile and the world will smile with you - The effects of a virtual agent's smile on users' evaluation and behavior. International Journal of Human-Computer Studies, 71(3), 335-349.

Kwon, J. H., Powell, J., \& Chalmers, A. (2013). How level of realism influences anxiety in virtual reality environments for a job interview. International Journal of Human-Computer Studies, 71(10), 978-987.

Leding, J. K., Horton, J. C., \& Wootan, S. S. (2015). The contrast effect with avatars. Computers in Human Behavior, 44, 118-123.

Lee, C., Rincon, G. A., Meyer, G., Hollerer, T., \& Bowman, D. (2013). The effects of visual realism on search tasks in mixed reality simulation. IEEE Transactions on Visualization and Computer Graphics, 19(4), 547-556.

Lee, J.-E. R. (2014). Does virtual diversity matter?: Effects of avatar-based diversity representation on willingness to express offline racial identity and avatar customization. Computers in Human Behavior, 36, 190-197. 
Lee, S., \& Choi, J. (2017). Enhancing user experience with conversational agent for movie recommendation: Effects of self-disclosure and reciprocity. International Journal of Human-Computer Studies, 103, 95-105.

Lee, Y., Kozar, K. A., \& Larsen, K. R. (2009). Avatar e-mail versus traditional e-mail: Perceptual difference and media selection difference. Decision Support Systems, 46(2), 451-467.

Lehto, T., \& Oinas-Kukkonen, H. (2011). Persuasive features in web-based alcohol and smoking interventions: A systematic review of the literature. Journal of Medical Internet Research, 13(3), e46.

Lester, P. M., \& King, C. M. (2009). Analog vs. digital instruction and learning: Teaching within first and second life environments. Journal of Computer-Mediated Communication, 14(3), 457-483.

Li, B. J., \& Lwin, M. O. (2016). Player see, player do: Testing an exergame motivation model based on the influence of the self avatar. Computers in Human Behavior, 59, 350-357.

Lim, S., \& Reeves, B. (2010). Computer agents versus avatars: Responses to interactive game characters controlled by a computer or other player. International Journal of HumanComputer Studies, 68(1), 57-68.

MacDorman, K. F., Green, R. D., Ho, C.-C., \& Koch, C. t. (2009). Too real for comfort? Uncanny responses to computer generated faces. Computers in Human Behavior, 25(3), 695-710.

MacDorman, K. F., \& Ishiguro, H. (2006). The uncanny advantage of using androids in social and cognitive science research. Interaction Studies, 7(3), 297-337.

Maldonado, H., Lee, J. R., Brave, S., Nass, C., Nakajima, H., Yamada, R., ... Morishima, Y. (2005). We learn better together: Enhancing eLearning with emotional characters. In Koschmann, T., Suthers, D., Chan, T.W. (Eds.), Proceedings of th 2005 Conference on Computer Support for Collaborative Learning: Learning 2005: The Next 10 Years! (pp. 408-417).

Mallan, K. M. (2009). Look at me! Look at me! Self-representation and self-exposure through online networks. Digital Culture and Education, 1(1), 51-66.

Mara, M., \& Appel, M. (2015). Science fiction reduces the eeriness of android robots: A field experiment. Computers in Human Behavior, 48, 156-162.

Martens, A. L., Grover, C. A., Saucier, D. A., \& Morrison, B. A. (2018). An examination of gender differences versus similarities in a virtual world. Computers in Human Behavior, $84,404-409$.

Mccreery, M. P., Krach, S. K., Schrader, P. G., \& Boone, R. (2012). Defining the virtual self: Personality, behavior, and the psychology of embodiment. Computers in Human Behavior, 28(3), 976-983.

McCroskey, J., Richmond, V., \& Daly, J. (1975). The development of a measure of perceived homophily in international communication. Human Communication Research, 1(4), 323 332.

Midha, V., \& Nandedkar, A. (2012). Impact of similarity between avatar and their users on their perceived identifiability: Evidence from virtual teams in Second Life platform. Computers in Human Behavior, 28(3), 929-932. 
Mitchell, W. J., Szerszen, K. A., Lu, A. S., Schermerhorn, P. W., Scheutz, M., \& MacDorman, K. F. (2011). A mismatch in the human realism of face and voice produces an uncanny valley. I-Perception, 2(1), 10-12.

Mori, M. (1970). Bukimi no tani (The uncanny valley). Energy, 7(4), 33-35.

Mousas, C., Anastasiou, D., \& Spantidi, O. (2018). The effects of appearance and motion of virtual characters on emotional reactivity. Computers in Human Behavior, 86, 99-108.

Nass, C., \& Moon, Y. (2000). Machines and mindlessness: Social responses to computers. Journal of Social Issues, 56(1), 81-103.

Nass, C., Steuer, J., \& Tauber, E. R. (1994). Computers are social actors. In Proceedings of the Conference on Human Factors in Computing Systems (pp. 72-78). Massachusetts, United States.

Noorbergen, T. J., Adam, M. T., Attia, J. R., Cornforth, D. J., \& Minichiello, M. (2019). Exploring the design of mHealth systems for health behavior change using mobile biosensors. Communications of the Association for Information Systems, 44, 944-981.

Nowak, K. L., \& Biocca, F. (2003). The effect of the agency and anthropomorphism on users' sense of telepresence, copresence, and social presence in virtual environments. Presence: Teleoperators and Virtual Environments, 12(5), 481-494.

Nowak, K. L., Fox, J., \& Ranjit, Y. S. (2015). Inferences about avatars: Sexism, appropriateness, anthropomorphism, and the objectification of female virtual representations. Journal of Computer-Mediated Communication, 20(5), 554-569.

Nowak, K. L., \& Rauh, C. (2006). The influence of the avatar on online perceptions of anthropomorphism, androgyny, credibility, homophily, and attraction. Journal of Computer-Mediated Communication, 11(2), 153-178.

Nowak, K. L., \& Rauh, C. (2008). Choose your "buddy icon" carefully: The influence of avatar androgyny, anthropomorphism and credibility in online interactions. Computers in Human Behavior, 24(4), 1473-1493.

Nunamaker, J. F., Derrick, D. C., Elkins, A. C., Burgoon, J. K., \& Patton, M. W. (2011). Embodied Conversational agent-based kiosk for automated interviewing. Journal of Management Information Systems, 28(1), 17-48.

Parise, S., Kiesler, S., Sproull, L., \& Waters, K. (1999). Cooperating with life-like interface agents. Computers in Human Behavior, 15(2), 123-142.

Peña, J., \& Chen, M. (2017). With great power comes great responsibility: Superhero primes and expansive poses influence prosocial behavior after a motion-controlled game task. Computers in Human Behavior, 76, 378-385.

Peña, J., Hancock, J. T., \& Merola, N. A. (2009). Thee priming effects of avatars in virtual settings. Communication Research, 36, 838-856.

Peña, J., Khan, S., \& Alexopoulos, C. (2016). I am what I see: How avatar and opponent agent body size affects physical activity among men playing exergames. Journal of ComputerMediated Communication, 21, 195-209.

Peña, J., \& Kim, E. (2014). Increasing exergame physical activity through self and opponent avatar appearance. Computers in Human Behavior, 41, 262-267. 
Pessoa, T. M., Coutinho, D. S., Pereira, V. M., De Oliveira Ribeiro, N. P., Nardi, A. E., \& De Oliveira e Silva, A. C. (2014). The Nintendo Wii as a tool for neurocognitive rehabilitation, training and health promotion. Computers in Human Behavior, 31(1), 384392.

Qiu, L., \& Benbasat, I. (2009). Evaluating anthropomorphic product recommendation agents: A social relationship perspective to designing information systems. Journal of Management Information Systems, 25(4), 145-182.

Qiu, L., \& Benbasat, I. (2010). A study of demographic embodiments of product recommendation agents in electronic commerce. International Journal of Human-Computer Studies, 68(10), 669-688.

Ratan, R. A., \& Dawson, M. (2016). When Mii is me: A psychophysiological examination of avatar self-relevance. Communication Research, 43(8), 1065-1093.

Ratan, R. A., \& Sah, Y. J. (2015). Leveling up on stereotype threat: The role of avatar customization and avatar embodiment. Computers in Human Behavior, 50, 367-374.

Ravaja, N., Saari, T., Salminen, M., Laarni, J., \& Kallinen, K. (2006). Phasic emotional reactions to video game events: A psychophysiological investigation. Media Psychology, 8(4), 343367.

Recker, J., Indulska, M., Green, P. F., Burton-jones, A., \& Weber, R. (2019). Information aystems as representations: A review of the theory and rvidence. Journal of the Association for Information Systems, 20(6), 735-786.

Riedl, R., Mohr, P. N. C., Kenning, P. H., Davis, F. D., \& Heekeren, H. R. (2011). Trusting humans and avatars: Behavioral and neural evidence. In ICIS Proceedings. Shanghai, China.

Riedl, R., Mohr, P. N. C., Kenning, P. H., Davis, F. D., \& Heekeren, H. R. (2014). Trusting humans and avatars: A brain imaging study based on evolution theory. Journal of Management Information Systems, 30(4), 83-114.

Rodrigues, L. F., Oliveira, A., \& Costa, C. J. (2016). Playing seriously - How gamification and social cues influence bank customers to use gamified e-business applications. Computers in Human Behavior, 63, 392-407.

Sanchez-Valdes, D., \& Trivino, G. (2015). Linguistic and emotional feedback for self-tracking physical activity. Expert Systems with Applications, 42(24), 9574-9586.

Saygin, A. P. (2011). The thing that should not be: Predictive coding and the uncanny valley in perceiving human and humanoid robot actions. Social Cognitive Affective Neuroscience, $7(4), 413-422$.

Schneider, F. M., Zwillich, B., Bindl, M. J., Hopp, F. R., Reich, S., \& Vorderer, P. (2017). Social media ostracism: The effects of being excluded online. Computers in Human Behavior, 73, 385-393.

Schultze, U. (2011). The Avatar as sociomaterial entanglement: A performative perspective on identity, agency and world-making in virtual worlds. In ICIS Proceedings. Shanghai, China. 
Sebastian, J., \& Richards, D. (2017). Changing stigmatizing attitudes to mental health via education and contact with embodied conversational agents. Computers in Human Behavior, 73, 479-488.

Seo, Y., Kim, M., Jung, Y., \& Lee, D. (2017). Avatar face recognition and self-presence. Computers in Human Behavior, 69, 120-127.

Shadish, W. R., Cook, T. D., \& Campbell, D. T. (2002). Experimental and quasi-experimental designs for generalized causal inference. Boston, MA: Houghton Mifflin.

Shedlosky-Shoemaker, R., Costabile, K. A., \& Arkin, R. M. (2014). Self-expansion through fictional characters. Self and Identity, 13(5), 556-578.

Slater, M., Khanna, P., Mortensen, J., \& Yu, I. (2009). Visual realism enhances realistic response in an immersive virtual. IEEE Computer Graphics and Applications, 29(3), 76-84.

Song, H., Kim, J., Kwon, R. J., \& Jung, Y. (2013). Anti-smoking educational game using avatars as visualized possible selves. Computers in Human Behavior, 29(5), 2029-2036.

Song, H., Kim, J., Tenzek, K. E., \& Lee, K. M. (2013). The effects of competition and competitiveness upon intrinsic motivation in exergames. Computers in Human Behavior, 29(4), 1702-1708.

Spence, P. R., Lachlan, K. A., Spates, S. A., \& Lin, X. (2013). Intercultural differences in responses to health messages on social media from spokespeople with varying levels of ethnic identity. Computers in Human Behavior, 29(3), 1255-1259.

Steuer, J. (1992). Defining virtual reality: Dimensions determining telepresence. Journal of Communication, 42(4), 73-93.

Strauss, P. S. (1990). A realistic lighting model for computer animators. IEEE Computer Graphics and Applications, 10(6), 56-64.

Suh, K., Kim, H., \& Suh, E. K. (2011). What if your avatar looks like you? Dual-congruity perspectives for avatar use. MIS Quarterly, 35(3), 711-729.

Sutcliffe, A., \& Alrayes, A. (2012). Investigating user experience in Second Life for collaborative learning. International Journal of Human-Computer Studies, 70(7), 508-525.

Sylvia, Z., King, T. K., \& Morse, B. J. (2014). Virtual ideals: The effect of video game play on male body image. Computers in Human Behavior, 37, 183-188.

Tamborini, R., Novotny, E., Prabhu, S., Hofer, M., Grall, C., Klebig, B., Hahn, L. S., Slaker, J., Ratan, R. A., Bente, G. (2018). The effect of behavioral synchrony with black or white virtual agents on outgroup trust. Computers in Human Behavior, 83, 176-183.

Tamborini, R., \& Skalski, P. (2006). The Role of Presence in the Experience of Electronic Games. In P. Vorderer \& J. Bryant (Eds.), Playing Video Games: Motivations, Responses, and Consequences (pp. 225-240). Mahwah, United States: Lawrence Earlbaum Associates.

Taylor, T. L. (2002). Living digitally: Embodiment in virtual worlds. In From R. Schroeder (Ed.)The Social Life of Avatars: Presence and Interaction in Shared Virtual Environments (pp. 40-62). London: Springer-Verlag.

Teng, C.-I. (2010). Customization, immersion satisfaction, and online gamer loyalty. Computers in Human Behavior, 26(6), 1547-1554. 
Teubner, T., Adam, M. T. P., Camacho, S., Hassanein, K. (2014). Understanding resource sharing in C2C platforms: The role of picture humanization. In ACIS Proceedings (pp. 110). Auckland, New Zealand.

Thomson, M., MacInnis, D. J., \& Park, W. (2005). The ties that bind: Measuring the strength of consumers' emotional attachments to brands. Journal of Consumer Psychology, 15(1), 7791.

Tinwell, A., Grimshaw, M., Abdel Nabi, D., \& Williams, A. (2011). Facial expression of emotion and perception of the Uncanny Valley in virtual characters. Computers in Human Behavior, 27(2), 741-749.

Vasalou, A., Joinson, A., Bänziger, T., Goldie, P., \& Pitt, J. (2008). Avatars in social media: Balancing accuracy, playfulness and embodied messages. International Journal of HumanComputer Studies, 66(11), 801-811.

Vasalou, A., \& Joinson, A. N. (2009). Me, myself and I: The role of interactional context on selfpresentation through avatars. Computers in Human Behavior, 25(2), 510-520.

von der Pütten, A. M., Krämer, N. C., Gratch, J., \& Kang, S. H. (2010). “It doesn't matter what you are!" Explaining social effects of agents and avatars. Computers in Human Behavior, 26(6), 1641-1650.

Walla, P., \& Panksepp, J. (2013). Neuroimaging helps to clarify brain affective processing without necessarily clarifying emotions. In Fountas K. N., ed., Novel Frontiers of Advanced Neuroimaging (pp. 93-118). IntechOpen.

Webster, J., \& Wong, W. K. P. (2008). Comparing traditional and virtual group forms: Identity, communication and trust in naturally occurring project teams. The International Journal of Human Resource Management, 19(1), 41-62.

Westerman, D., Tamborini, R., \& Bowman, N. D. (2015). The effects of static avatars on impression formation across different contexts on social networking sites. Computers in Human Behavior, 53, 111-117.

Won, A. S., Bailenson, J., Lee, J., \& Lanier, J. (2015). Homuncular flexibility in virtual reality. Journal of Computer-Mediated Communication, 20(3), 241-259.

Wrzesien, M., Rodríguez, A., Rey, B., Alcañiz, M., Baños, R. M., \& Vara, M. D. (2015). How the physical similarity of avatars can influence the learning of emotion regulation strategies in teenagers. Computers in Human Behavior, 43, 101-111.

Wu, J., Mattingly, E., \& Kraemer, P. (2015). Communication in virtual environments: The influence of spatial cues and gender on verbal behavior. Computers in Human Behavior, $52,59-64$.

Yee, N., \& Bailenson, J. N. (2007). The Proteus effect: The effect of transformed selfrepresentation on behavior. Human Communication Research, 33(3), 271-290.

Yee, N., Bailenson, J. N., \& Ducheneaut, N. (2009). The Proteus effect: Implications of transformed digital self-representation on online and offline behavior. Communication Research, 36(2), 285-312.

Yusof, S. A. M., \& Zakaria, N. (2007). Islamic perspective: Virtual worlds as a western-centric technology. SIGMIS Database, 38(4), 100-103. 


\section{Appendix A: Literature Summary Table}

Table A1. Experimental Studies on Avatars and Embodied Agents in IS Literature.

\begin{tabular}{|c|c|c|c|c|c|}
\hline $\begin{array}{l}\text { Authors (year) } \\
\text { [Outlet] }\end{array}$ & Brief Description & \begin{tabular}{|c|} 
Avatar / Embodied \\
Agent Design \\
[Interaction]
\end{tabular} & $\begin{array}{l}\text { Application } \\
\text { [Context] }\end{array}$ & $\begin{array}{l}\text { Psychological } \\
\text { Construct(s) }\end{array}$ & \#P (Env) \\
\hline $\begin{array}{l}\text { Gerhard et al. } \\
(2004) \text { [IJHCS] }\end{array}$ & $\begin{array}{l}\text { Explores hybrid avatar/agent model to } \\
\text { achieve permanent users' presence and } \\
\text { increase user experience }\end{array}$ & $\begin{array}{l}\text { full body, motion, } \\
\text { 3D [SA2A/SA2EA] }\end{array}$ & $\begin{array}{l}\text { collaboration } \\
\text { [business] }\end{array}$ & $\begin{array}{l}\text { awareness, immersion, } \\
\text { involvement, presence }\end{array}$ & $20(\mathrm{Lab})$ \\
\hline \begin{tabular}{|l} 
Brave et al. \\
(2005) [IJHCS]
\end{tabular} & $\begin{array}{l}\text { Effects of an embodied agent's } \\
\text { emotions upon users }\end{array}$ & $\begin{array}{l}\text { face only, static, 2D } \\
\text { [H2EA] }\end{array}$ & $\begin{array}{l}\text { blackjack game } \\
\text { [entertainment] }\end{array}$ & $\begin{array}{l}\text { emotionality, } \\
\text { likeability, trust }\end{array}$ & 96 (Lab) \\
\hline $\begin{array}{l}\text { Nowak \& Rauh } \\
(2006)[\mathrm{JCMC}]\end{array}$ & $\begin{array}{l}\text { Effects of avatars physical appearance } \\
\text { on users' perceptions }\end{array}$ & $\begin{array}{l}\text { face only, static, 2D } \\
{[\mathrm{H} 2 \mathrm{~A}]}\end{array}$ & $\begin{array}{l}\text { interaction } \\
{[\text { social }]}\end{array}$ & $\begin{array}{l}\text { androgyny, } \\
\text { anthropomorphism, } \\
\text { attractiveness, } \\
\text { credibility, intention to } \\
\text { use, similarity }\end{array}$ & 255 (Lab) \\
\hline $\begin{array}{l}\text { Galanxhi \& Nah } \\
(2007) \text { [IJHCS] }\end{array}$ & $\begin{array}{l}\text { Effects of avatars on deceptions vs. } \\
\text { truth on users in online chats }\end{array}$ & \begin{tabular}{|l|} 
face only, static, 2D \\
{$[\mathrm{SA} 2 \mathrm{~A}]$}
\end{tabular} & \begin{tabular}{|l} 
interaction \\
[social]
\end{tabular} & $\begin{array}{l}\text { deceptiveness, } \\
\text { intention to use, trust, } \\
\text { user anxiety }\end{array}$ & 94 (Lab) \\
\hline \begin{tabular}{|l|} 
Gong (2007) \\
[IJHCS]
\end{tabular} & $\begin{array}{l}\text { Effects of a happy talking-head EA on } \\
\text { users' trustworthiness, and } \\
\text { competence of the EA }\end{array}$ & $\begin{array}{l}\text { face only, motion, } \\
2 \mathrm{D}[\mathrm{H} 2 \mathrm{EA}]\end{array}$ & $\begin{array}{l}\text { book review } \\
\text { [entertainment] }\end{array}$ & $\begin{array}{l}\text { competence, } \\
\text { emotionality, intention } \\
\text { to use, likeability, trust }\end{array}$ & 24 (Lab) \\
\hline $\begin{array}{l}\text { Hämäläinen et } \\
\text { al. (2008) [CHB] }\end{array}$ & $\begin{array}{l}\text { Effects of avatars on group learning } \\
\text { activity performance in collaborative } \\
\text { environments }\end{array}$ & $\begin{array}{l}\text { full body, motion, } \\
\text { 3D }[\mathrm{SA} 2 \mathrm{~A}]\end{array}$ & $\begin{array}{l}\text { collaboration } \\
\text { [education] }\end{array}$ & knowledgeability & 64 (Lab) \\
\hline $\begin{array}{l}\text { Nowak \& Rauh } \\
(2008) \text { [CHB] }\end{array}$ & $\begin{array}{l}\text { Effects of a user's avatar on other's } \\
\text { perceptions of the avatar }\end{array}$ & \begin{tabular}{|l|} 
face only, static, 2D \\
{$[\mathrm{H} 2 \mathrm{~A}]$}
\end{tabular} & \begin{tabular}{|l} 
interaction \\
[social]
\end{tabular} & $\begin{array}{l}\text { androgyny, } \\
\text { anthropomorphism, } \\
\text { credibility }\end{array}$ & $\begin{array}{l}255 \text { (srv) } \\
230 \text { (Lab) }\end{array}$ \\
\hline $\begin{array}{l}\text { Vasalou et al. } \\
(2008) \text { [IJHCS] }\end{array}$ & $\begin{array}{l}\text { How users present themselves via } \\
\text { avatar in social media (actual self and } \\
\text { ideal self) }\end{array}$ & $\begin{array}{l}\text { full body, motion, } \\
3 \mathrm{D}[\mathrm{H} 2 \mathrm{SA}]\end{array}$ & $\begin{array}{l}\text { social media } \\
{[\text { social }]}\end{array}$ & $\begin{array}{l}\text { emotional attachment, } \\
\text { self-representativeness }\end{array}$ & $20(\mathrm{Lab})$ \\
\hline $\begin{array}{l}\text { Franceschi et al. } \\
(2009)[\text { JMIS] }\end{array}$ & $\begin{array}{l}\text { Compares presence in text-based } \\
\text { virtual environment (blackboard), } \\
\text { virtual world (second life), classroom }\end{array}$ & $\begin{array}{l}\text { full body, motion, } \\
2 \mathrm{D} / 3 \mathrm{D}[\mathrm{SA} 2 \mathrm{~A}]\end{array}$ & \begin{tabular}{|l} 
eLearning \\
[education]
\end{tabular} & $\begin{array}{l}\text { group presence, } \\
\text { presence, user } \\
\text { engagement }\end{array}$ & $\begin{array}{l}24 \text { N. A. } \\
24 \text { (Fld) } \\
24 \text { N. A. }\end{array}$ \\
\hline $\begin{array}{l}\text { Groom et al. } \\
(2009) \text { [IJHCS] }\end{array}$ & $\begin{array}{l}\text { Effects of EA's behavioural realism on } \\
\text { people's responses }\end{array}$ & $\begin{array}{l}\text { full body, motion, } \\
\text { 3D [H2EA] }\end{array}$ & $\begin{array}{l}\text { survival game } \\
\text { [entertainment] }\end{array}$ & $\begin{array}{l}\text { likeability, } \\
\text { persuasiveness, } \\
\text { behavioural realism, } \\
\text { user comfort }\end{array}$ & $80(\mathrm{Lab})$ \\
\hline $\begin{array}{l}\text { J. Kim (2009) } \\
{[\mathrm{CHB}]}\end{array}$ & $\begin{array}{l}\text { Effects of avatars' visual similarity on } \\
\text { group identity and conformity }\end{array}$ & $\begin{array}{l}\text { face only, static, 2D } \\
\text { [SA2A] }\end{array}$ & $\begin{array}{l}\text { group identity } \\
\text { [social] }\end{array}$ & similarity & $164(\mathrm{Lab})$ \\
\hline $\begin{array}{l}\text { Y. Lee et al. } \\
(2009) \text { [DSS] }\end{array}$ & $\begin{array}{l}\text { Explores how users perceive avatar } \\
\text { email differently from traditional email }\end{array}$ & $\begin{array}{l}\text { full and half body, } \\
\text { static, 2D [H2A] }\end{array}$ & $\begin{array}{l}\text { communication } \\
\text { [business] }\end{array}$ & $\begin{array}{l}\text { intention to use, } \\
\text { presence }\end{array}$ & $\begin{array}{l}742 \text { (srv) } \\
505 \text { (srv) } \\
452 \text { (Lab) }\end{array}$ \\
\hline $\begin{array}{l}\text { Lester \& King } \\
(2009) \text { [JCMC] }\end{array}$ & $\begin{array}{l}\text { The study compares student } \\
\text { performance between traditional } \\
\text { classroom and virtual classroom } \\
\text { (blackboard and second life) }\end{array}$ & $\begin{array}{l}\text { full body, motion, } \\
\text { 2D/3D [SA2A] }\end{array}$ & \begin{tabular}{|l} 
classroom \\
[education]
\end{tabular} & knowledgeability & $\begin{array}{l}161 \text { (Fld) } \\
173 \text { (Fld) }\end{array}$ \\
\hline $\begin{array}{l}\text { Qiu \& Benbasat } \\
\text { (2009) [JMIS] }\end{array}$ & $\begin{array}{l}\text { Effects of an embodied agent on users' } \\
\text { social presence, trust, and enjoyment }\end{array}$ & $\begin{array}{l}\text { half body, static, 2D } \\
\text { [H2EA] }\end{array}$ & $\begin{array}{l}\text { eCommerce } \\
\text { [business] }\end{array}$ & $\begin{array}{l}\text { enjoyment, intention to } \\
\text { use, presence, trust, } \\
\text { usefulness }\end{array}$ & $168(\mathrm{Lab})$ \\
\hline $\begin{array}{l}\text { Vasalou \& } \\
\text { Joinson (2009) } \\
{[\mathrm{CHB}]}\end{array}$ & $\begin{array}{l}\text { Explores the different self-presentation } \\
\text { designs via avatar for blogging, dating, } \\
\text { \& gaming }\end{array}$ & $\begin{array}{l}\text { full body, static, 3D } \\
{[\mathrm{H} 2 \mathrm{SA}]}\end{array}$ & $\begin{array}{l}\text { blogging, } \\
\text { dating, gaming } \\
\text { [social] }\end{array}$ & $\begin{array}{l}\text { attractiveness, self- } \\
\text { awareness, self- } \\
\text { representativeness, } \\
\text { similarity }\end{array}$ & 71 (Lab) \\
\hline
\end{tabular}




\begin{tabular}{|c|c|c|c|c|c|}
\hline $\begin{array}{c}\text { Authors (year) } \\
\text { [Outlet] }\end{array}$ & Brief Description & \begin{tabular}{|c|} 
Avatar / Embodied \\
Agent Design \\
[Interaction]
\end{tabular} & $\begin{array}{c}\text { Application } \\
\text { [Context] }\end{array}$ & $\begin{array}{l}\text { Psychological } \\
\text { Construct(s) }\end{array}$ & \#P (Env) \\
\hline $\begin{array}{l}\text { Huang et al. } \\
(2010) \text { [CHB] }\end{array}$ & $\begin{array}{l}\text { Effects of avatars on team's } \\
\text { performance interaction in a virtual } \\
\text { meeting }\end{array}$ & $\begin{array}{l}\text { full body, motion, } \\
3 \mathrm{D}[\mathrm{SA} 2 \mathrm{~A}]\end{array}$ & $\begin{array}{l}\text { virtual meeting } \\
\text { [business] }\end{array}$ & $\begin{array}{l}\text { cooperativeness, } \\
\text { satisfaction }\end{array}$ & 485 (Lab) \\
\hline \begin{tabular}{|l} 
Jin $(2010)$ \\
{$[\mathrm{CHB}]$}
\end{tabular} & $\begin{array}{l}\text { Effects of a virtual agent on enjoyment } \\
\text { and evaluation of computer-aided } \\
\text { education }\end{array}$ & $\begin{array}{l}\text { full body, motion, } \\
3 \mathrm{D} \text { [SA2EA] }\end{array}$ & $\begin{array}{l}\text { stress } \\
\text { management } \\
{[\text { health] }}\end{array}$ & $\begin{array}{l}\text { educational value, } \\
\text { enjoyment, self- } \\
\text { efficacy }\end{array}$ & $60(\mathrm{Lab})$ \\
\hline $\begin{array}{l}\text { Qiu \& Benbasat } \\
\text { (2010) [IJHCS] }\end{array}$ & $\begin{array}{l}\text { Effects of an embodied agent on users' } \\
\text { social experience }\end{array}$ & $\begin{array}{l}\text { half body, static, 2D } \\
\text { [H2EA] }\end{array}$ & $\begin{array}{l}\text { eCommerce } \\
\text { [business] }\end{array}$ & $\begin{array}{l}\text { enjoyment, intention to } \\
\text { use, presence, } \\
\text { usefulness }\end{array}$ & $188(\mathrm{Lab})$ \\
\hline $\begin{array}{l}\text { von der Pütten et } \\
\text { al. (2010) [CHB] }\end{array}$ & $\begin{array}{l}\text { Evaluates whether interacting with } \\
\text { either an avatar or an agent lead to } \\
\text { higher level of attention }\end{array}$ & $\begin{array}{l}\text { full body, motion, } \\
\text { 3D }[\mathrm{H} 2 \mathrm{EA} / \mathrm{H} 2 \mathrm{~A}]\end{array}$ & $\begin{array}{l}\text { social } \\
\text { behaviour } \\
\text { [social] }\end{array}$ & $\begin{array}{l}\text { behavioural realism, } \\
\text { presence, rapport }\end{array}$ & 83 (Lab) \\
\hline $\begin{array}{l}\text { Guadagno et al. } \\
(2011) \text { [CHB] }\end{array}$ & $\begin{array}{l}\text { Effects of empathy on people when } \\
\text { interacting with virtual human } \\
\text { representation }\end{array}$ & $\begin{array}{l}\text { full body, motion, } \\
\text { 3D [SA2A/SA2EA] }\end{array}$ & $\begin{array}{l}\text { interaction } \\
{[\text { social }]}\end{array}$ & $\begin{array}{l}\text { emotionality, } \\
\text { enjoyment, likeability, } \\
\text { presence, satisfaction, } \\
\text { trust, user comfort, } \\
\text { supportiveness }\end{array}$ & 38 (Lab) \\
\hline \begin{tabular}{|l} 
J. $\operatorname{Kim}(2011)$ \\
{$[$ JCMC] }
\end{tabular} & $\begin{array}{l}\text { Explores how group visual similarity } \\
\text { strengthen the group identification }\end{array}$ & $\begin{array}{l}\text { face only, static, 2D } \\
{[\mathrm{H} 2 \mathrm{~A}]}\end{array}$ & $\begin{array}{l}\text { discussion } \\
\text { [business] }\end{array}$ & similarity & $258(\mathrm{Lab})$ \\
\hline $\begin{array}{l}\text { J. Kim \& Park } \\
(2011) \text { [CHB] }\end{array}$ & $\begin{array}{l}\text { Effects of an avatar's uniform } \\
\text { appearance on users' willingness to } \\
\text { agree to a majority opinion in virtual } \\
\text { groups }\end{array}$ & $\begin{array}{l}\text { face only, static, 2D } \\
\text { [SA2A] }\end{array}$ & $\begin{array}{l}\text { discussion } \\
\text { [social] }\end{array}$ & simila & $345(\mathrm{Lab})$ \\
\hline $\begin{array}{l}\text { Nunamaker et al. } \\
(2011) \text { [JMIS] }\end{array}$ & $\begin{array}{l}\text { Effects of an automated interviewing } \\
\text { agent on arousal, behaviour, and } \\
\text { cognitive effort }\end{array}$ & $\begin{array}{l}\text { face only, motion, } \\
3 \mathrm{D}[\mathrm{H} 2 \mathrm{EA}]\end{array}$ & $\begin{array}{l}\text { interv } \\
\text { [busir }\end{array}$ & $\begin{array}{l}\text { knowledgeability, } \\
\text { likeability, trust }\end{array}$ & $\begin{array}{l}88 \text { (Lab) } \\
81 \text { (Lab) } \\
29 \text { (Fld) }\end{array}$ \\
\hline $\begin{array}{l}\text { Riedl et al. } \\
(2011) \text { [ICIS] }\end{array}$ & $\begin{array}{l}\text { Investigates trust in terms of } \\
\text { participants playing against humans or } \\
\text { against embodied agent }\end{array}$ & $\begin{array}{l}\text { face only, static, 2D } \\
{[\mathrm{H} 2 \mathrm{H} / \mathrm{H} 2 \mathrm{EA}]}\end{array}$ & $\begin{array}{l}\text { trust game } \\
\text { [business] }\end{array}$ & trust & $18(\mathrm{Lab})$ \\
\hline \begin{tabular}{|l|} 
Schultze (2011) \\
[ICIS]
\end{tabular} & $\begin{array}{l}\text { Explores how virtual worlds users } \\
\text { construct agency (possible and ideal } \\
\text { self), identity, and worlds within in- } \\
\text { worlds experience }\end{array}$ & $\begin{array}{l}\text { full body, motion, } \\
\text { 3D [H2SA] }\end{array}$ & \begin{tabular}{|l|} 
second life \\
[entertainment]
\end{tabular} & age & 35 (Lab) \\
\hline \begin{tabular}{|l} 
Suh et al. (2011) \\
[MISQ]
\end{tabular} & $\begin{array}{l}\text { Explores effects of avatar similarity to } \\
\text { actual self on users' attitudes toward } \\
\text { the use of avatar and identification }\end{array}$ & $\begin{array}{l}\text { full body, motion, } \\
\text { 2D/3D [H2SA] }\end{array}$ & $\begin{array}{l}\text { virtual store } \\
\text { [business] }\end{array}$ & $\begin{array}{l}\text { intention to use, } \\
\text { similarity }\end{array}$ & 92 (Lab) \\
\hline $\begin{array}{l}\text { Dunn \& } \\
\text { Guadagno } \\
(2012)[\mathrm{CHB}]\end{array}$ & $\begin{array}{l}\text { Effects of users' gender and } \\
\text { personality type on avatar } \\
\text { representation }\end{array}$ & $\begin{array}{l}\text { full body, motion, } \\
\text { 3D }[\mathrm{SA} 2 \mathrm{~A}]\end{array}$ & \begin{tabular}{|l} 
video game \\
[entertainment]
\end{tabular} & \begin{tabular}{|l|} 
gender, personality \\
type, self-esteem, self- \\
representativeness
\end{tabular} & 174 (Lab) \\
\hline $\begin{array}{l}\text { Jin (2012) } \\
{[\mathrm{CHB}]}\end{array}$ & $\begin{array}{l}\text { Effects on avatars on user's self- } \\
\text { disclosure interpersonal } \\
\text { communication }\end{array}$ & $\begin{array}{l}\text { full body, motion, } \\
\text { 3D [SA2A] }\end{array}$ & $\begin{array}{l}\text { interaction } \\
{[\text { social }]}\end{array}$ & presence, trust & $\begin{array}{l}117 \text { (Lab) } \\
148 \text { (Lab) }\end{array}$ \\
\hline $\begin{array}{l}\text { Y. Kim \& } \\
\text { Sundar (2012a) } \\
{[\mathrm{CHB}]}\end{array}$ & $\begin{array}{l}\text { Effects of computer } \\
\text { anthropomorphism on presence and } \\
\text { credibility }\end{array}$ & $\begin{array}{l}\text { full body, motion, } \\
2 \mathrm{D}[\mathrm{H} 2 \mathrm{EA}]\end{array}$ & $\begin{array}{l}\text { health } \\
\text { information } \\
{[\text { health] }}\end{array}$ & $\begin{array}{l}\text { anthropomorphism, } \\
\text { credibility, presence }\end{array}$ & $93(\mathrm{Lab})$ \\
\hline $\begin{array}{l}\text { Y. Kim \& } \\
\text { Sundar }(2012 b) \\
{[\mathrm{CHB}]}\end{array}$ & $\begin{array}{l}\text { Effects of realistic self-avatar on risk- } \\
\text { taking behaviour }\end{array}$ & $\begin{array}{l}\text { full body, motion, } \\
\text { 3D [SA2EA] }\end{array}$ & $\begin{array}{l}\text { health } \\
\text { information } \\
\text { [health] }\end{array}$ & $\begin{array}{l}\text { attractiveness, visual } \\
\text { realism }\end{array}$ & 95 (Lab) \\
\hline $\begin{array}{l}\text { Mccreery et al. } \\
(2012)[\mathrm{CHB}]\end{array}$ & $\begin{array}{l}\text { Effects of the big five personality } \\
\text { dimensions on users' helping } \\
\text { behaviour in virtual environment }\end{array}$ & $\begin{array}{l}\text { full body, motion, } \\
\text { 3D [SA2A] }\end{array}$ & \begin{tabular}{|l|} 
video game \\
[entertainment]
\end{tabular} & $\begin{array}{l}\text { personality type, self- } \\
\text { interest, self- } \\
\text { representativeness }\end{array}$ & 39 (Lab) \\
\hline $\begin{array}{l}\text { Sutcliffe \& } \\
\text { Alrayes (2012) } \\
\text { [IJHCS] }\end{array}$ & $\begin{array}{l}\text { The study compares students' } \\
\text { performance in blackboard and second } \\
\text { life in terms of usability and user } \\
\text { experience }\end{array}$ & $\begin{array}{l}\text { full body, motion, } \\
\text { 2D/3D [SA2A] }\end{array}$ & $\begin{array}{l}\text { collaboration } \\
\text { [education] }\end{array}$ & $\begin{array}{l}\text { emotionality, presence, } \\
\text { user collaboration }\end{array}$ & $\begin{array}{l}38(\mathrm{Lab}) \\
63(\mathrm{Lab})\end{array}$ \\
\hline $\begin{array}{l}\text { Ang et al. (2013) } \\
\text { [CHB] }\end{array}$ & $\begin{array}{l}\text { Effects of avatar body gestures on } \\
\text { performance and satisfaction in school } \\
\text { tasks }\end{array}$ & $\begin{array}{l}\text { full body, motion, } \\
3 \mathrm{D}[\mathrm{SA} 2 \mathrm{~A}]\end{array}$ & $\begin{array}{l}\text { school task } \\
\text { [education] }\end{array}$ & $\begin{array}{l}\text { intelligence, } \\
\text { likeability, satisfaction, } \\
\text { trust }\end{array}$ & 64 (Lab) \\
\hline
\end{tabular}




\begin{tabular}{|c|c|c|c|c|c|}
\hline $\begin{array}{c}\text { Authors (year) } \\
\text { [Outlet] }\end{array}$ & Brief Description & \begin{tabular}{|c|} 
Avatar / Embodied \\
Agent Design \\
[Interaction]
\end{tabular} & $\begin{array}{c}\text { Application } \\
\text { [Context] }\end{array}$ & $\begin{array}{l}\text { Psychological } \\
\text { Construct(s) }\end{array}$ & \#P (Env) \\
\hline $\begin{array}{l}\text { Fox et al. (2013) } \\
{[\text { CHB] }}\end{array}$ & $\begin{array}{l}\text { Influences of choosing avatar that is } \\
\text { sexualised or non-sexualised on user's } \\
\text { self-objectification }\end{array}$ & $\begin{array}{l}\text { full body, motion, } \\
\text { 3D [H2SA/SA2A] }\end{array}$ & $\begin{array}{l}\text { interaction } \\
{[\text { social }]}\end{array}$ & $\begin{array}{l}\text { intention to use, } \\
\text { presence }\end{array}$ & $86(\mathrm{Lab})$ \\
\hline $\begin{array}{l}\text { Goel et al. } \\
(2013) \text { [ISJ] }\end{array}$ & $\begin{array}{l}\text { Investigates what influences users to } \\
\text { return to a virtual world }\end{array}$ & $\begin{array}{l}\text { full body, motion, } \\
\text { 3D [SA2A] }\end{array}$ & $\begin{array}{l}\text { interaction } \\
{[\text { social }]}\end{array}$ & $\begin{array}{l}\text { immersion, intention to } \\
\text { return, presence, social } \\
\text { awareness }\end{array}$ & 175 (Lab) \\
\hline $\begin{array}{l}\text { Kang \& Watt } \\
(2013)[\text { CHB] }\end{array}$ & $\begin{array}{l}\text { Effects of avatar realism on } \\
\text { communication socially }\end{array}$ & $\begin{array}{l}\text { face only, motion, } \\
2 \mathrm{D}[\mathrm{H} 2 \mathrm{~A}]\end{array}$ & $\begin{array}{l}\text { communication } \\
\text { [social] }\end{array}$ & $\begin{array}{l}\text { anthropomorphism, } \\
\text { presence, realism } \\
\text { (visual, behavioural), } \\
\text { satisfaction }\end{array}$ & 198 (Lab) \\
\hline \begin{tabular}{|l|} 
Keng \& Liu \\
$(2013)[\mathrm{CHB}]$
\end{tabular} & $\begin{array}{l}\text { Effects of an avatar's attractiveness on } \\
\text { online advertisement }\end{array}$ & $\begin{array}{l}\text { face only, static, 2D } \\
{[\mathrm{H} 2 \mathrm{~A}]}\end{array}$ & \begin{tabular}{|l} 
advertising \\
[business]
\end{tabular} & $\begin{array}{l}\text { attractiveness, } \\
\text { purchase intention }\end{array}$ & $\begin{array}{l}1514 \text { (lab) } \\
687 \text { (Lab) }\end{array}$ \\
\hline $\begin{array}{l}\text { Krämer et al. } \\
\text { (2013) [IJHCS] }\end{array}$ & $\begin{array}{l}\text { Effects of an agent's smile on } \\
\text { participants' evolution and smiling } \\
\text { behaviour }\end{array}$ & $\begin{array}{l}\text { half body, motion, } \\
3 \mathrm{D}[\mathrm{H} 2 \mathrm{EA}]\end{array}$ & $\begin{array}{l}\text { conversation } \\
\text { (smiling) } \\
\text { [social] }\end{array}$ & $\begin{array}{l}\text { anthropomorphism, } \\
\text { emotionality (smile) }\end{array}$ & $104(\mathrm{Lab})$ \\
\hline $\begin{array}{l}\text { Kwon et al. } \\
\text { (2013) [IJHCS] }\end{array}$ & $\begin{array}{l}\text { Effects of various virtual environment } \\
\text { conditions upon users' level of anxiety }\end{array}$ & $\begin{array}{l}\text { half body, motion, } \\
2 \mathrm{D} / 3 \mathrm{D} \text { [H2EA] }\end{array}$ & $\begin{array}{l}\text { job interview } \\
\text { [business] }\end{array}$ & $\begin{array}{l}\text { visual realism, user } \\
\text { anxiety }\end{array}$ & $\begin{array}{l}60 \text { (Lab) } \\
20 \text { (Lab) }\end{array}$ \\
\hline $\begin{array}{l}\text { Song, Kim, } \\
\text { Kwon, et al. } \\
(2013)[\mathrm{CHB}]\end{array}$ & $\begin{array}{l}\text { Effects of smoking avatar } \\
\text { representations on users' perceived } \\
\text { risk of smoking }\end{array}$ & $\begin{array}{l}\text { full body, motion, } \\
\text { 3D [H2SA] }\end{array}$ & $\begin{array}{l}\text { game } \\
\text { [education] }\end{array}$ & $\begin{array}{l}\text { identification, } \\
\text { intention to quit }\end{array}$ & $62(\mathrm{Lab})$ \\
\hline $\begin{array}{l}\text { Song, Kim, } \\
\text { Tenzek, et al. } \\
(2013)[\mathrm{CHB}]\end{array}$ & $\begin{array}{l}\text { Effects of an avatar on competing in } \\
\text { exercise video games on users' playing } \\
\text { time }\end{array}$ & $\begin{array}{l}\text { full body, motion, } \\
3 \mathrm{D}[\mathrm{SA} 2 \mathrm{~A}]\end{array}$ & inment] & \begin{tabular}{|l|} 
competitiveness, \\
enjoyment, mood, self- \\
efficacy
\end{tabular} & $72(\mathrm{Lab})$ \\
\hline $\begin{array}{l}\text { Spence et al. } \\
(2013)[\mathrm{CHB}]\end{array}$ & $\begin{array}{l}\text { Effects of the avatar ethnicity and } \\
\text { similarity on health-related } \\
\text { information }\end{array}$ & $\begin{array}{l}\text { face/ shoulder only, } \\
\text { static, } 2 \mathrm{D}[\mathrm{H} 2 \mathrm{~A}]\end{array}$ & $\begin{array}{l}\text { communication } \\
\text { [health] }\end{array}$ & $\begin{array}{l}\text { behavioural intentions, } \\
\text { similarity (ethnicity) }\end{array}$ & 207 (Lab) \\
\hline $\begin{array}{l}\text { Dolgov et al. } \\
(2014)[\mathrm{CHB}]\end{array}$ & $\begin{array}{l}\text { Effects of avatar customisation on } \\
\text { helping behaviour }\end{array}$ & $\begin{array}{l}\text { full body, motion, } \\
\text { 3D }[\mathrm{SA} 2 \mathrm{~A}]\end{array}$ & $\begin{array}{l}\text { video game } \\
\text { [entertainment] }\end{array}$ & $\begin{array}{l}\text { identification, } \\
\text { similarity }\end{array}$ & $\begin{array}{l}54(\mathrm{Lab}) \\
25(\mathrm{Lab})\end{array}$ \\
\hline $\begin{array}{l}\text { Felnhofer et al. } \\
(2014) \text { [CHB] }\end{array}$ & $\begin{array}{l}\text { Effects of users' gender and age on } \\
\text { presence, empathy, and collaboration }\end{array}$ & $\begin{array}{l}\text { full body, motion, } \\
\text { 3D }[\mathrm{SA} 2 \mathrm{~A}]\end{array}$ & café & $\begin{array}{l}\text { empathy, gender, } \\
\text { presence }\end{array}$ & $124(\mathrm{Lab})$ \\
\hline $\begin{array}{l}\text { Grinberg et al. } \\
\text { (2014) [CHB] }\end{array}$ & $\begin{array}{l}\text { Effects of avatar on social engagement } \\
\text { and immersion in the virtual } \\
\text { environment }\end{array}$ & $\begin{array}{l}\text { full body, motion, } \\
3 \mathrm{D}[\mathrm{SA} 2 \mathrm{~A}]\end{array}$ & $\begin{array}{l}\text { interaction } \\
\text { [social] }\end{array}$ & $\begin{array}{l}\text { immersion, presence, } \\
\text { user engagement }\end{array}$ & 35 (Lab) \\
\hline $\begin{array}{l}\text { Hammick \& Lee } \\
\text { (2014) [CHB] }\end{array}$ & $\begin{array}{l}\text { Effects of an avatar on shy users to } \\
\text { express themselves freely }\end{array}$ & $\begin{array}{l}\text { full body, motion, } \\
\text { 3D [SA2A] }\end{array}$ & $\begin{array}{l}\text { communication } \\
\text { [social] }\end{array}$ & interactivit & $58(\mathrm{Lab})$ \\
\hline $\begin{array}{l}\text { Kang \& Gratch } \\
(2014) \text { [CHB] }\end{array}$ & $\begin{array}{l}\text { Effects of embodied agents' } \\
\text { behavioural realism on users' self- } \\
\text { disclosure }\end{array}$ & $\begin{array}{l}\text { half body, motion, } \\
\text { 3D [H2EA] }\end{array}$ & $\begin{array}{l}\text { counselling } \\
\text { interviews } \\
\text { [social] }\end{array}$ & $\begin{array}{l}\text { behavioural realism, } \\
\text { emotional state, } \\
\text { presence, likeability }\end{array}$ & $171(\mathrm{Lab})$ \\
\hline \begin{tabular}{|l|} 
J.-E. R. Lee \\
(2014) [CHB]
\end{tabular} & $\begin{array}{l}\text { Effects of avatar' diversity on offline } \\
\text { racial identity }\end{array}$ & $\begin{array}{l}\text { half body, motion, } \\
3 \mathrm{D}[\mathrm{H} 2 \mathrm{~A}]\end{array}$ & $\begin{array}{l}\text { social identity } \\
\text { [social] }\end{array}$ & $\begin{array}{l}\text { user willing to reveal } \\
\text { racial identity }\end{array}$ & $56(\mathrm{Lab})$ \\
\hline $\begin{array}{l}\text { Peña \& Kim } \\
(2014)[\text { CHB] }\end{array}$ & $\begin{array}{l}\text { Effects of avatars' size on physical } \\
\text { activity in exergame using } \\
\text { accelerometers }\end{array}$ & $\begin{array}{l}\text { full body, motion, } \\
\text { 3D }[\mathrm{SA} 2 \mathrm{~A}]\end{array}$ & $\begin{array}{l}\text { video game } \\
\text { [entertainment] }\end{array}$ & $\mathrm{NA}$ & 96 (Lab) \\
\hline \begin{tabular}{|l} 
Riedl et al. \\
(2014) [JMIS]
\end{tabular} & $\begin{array}{l}\text { Investigates trust in terms of } \\
\text { participants playing against humans or } \\
\text { against embodied agent to make } \\
\text { decision and learn }\end{array}$ & $\begin{array}{l}\text { face only, static, 2D } \\
{[\mathrm{H} 2 \mathrm{H} / \mathrm{H} 2 \mathrm{EA}]}\end{array}$ & $\begin{array}{l}\text { trust Game } \\
\text { [business] }\end{array}$ & trust & $18(\mathrm{Lab})$ \\
\hline \begin{tabular}{|l} 
Sylvia et al. \\
$(2014)[\mathrm{CHB}]$
\end{tabular} & $\begin{array}{l}\text { Effects of playing video games with an } \\
\text { unrealistic male body on actual body } \\
\text { satisfaction }\end{array}$ & $\begin{array}{l}\text { full body, motion, } \\
3 \mathrm{D}[\mathrm{H} 2 \mathrm{SA}]\end{array}$ & $\begin{array}{l}\text { video game } \\
\text { [entertainment] }\end{array}$ & $\begin{array}{l}\text { satisfaction, body and } \\
\text { self-esteem }\end{array}$ & 50 (Lab) \\
\hline $\begin{array}{l}\text { Hanus \& Fox } \\
\text { (2015) [IJHCS] }\end{array}$ & $\begin{array}{l}\text { Effect of customising an avatar on } \\
\text { intrinsic motivation, brand liking and } \\
\text { purchase intention }\end{array}$ & $\begin{array}{l}\text { full body, motion, } \\
\text { 3D [SA2A] }\end{array}$ & sale [business] & $\begin{array}{l}\text { agency, likeability, } \\
\text { motivation, purchase } \\
\text { intention }\end{array}$ & $80(\mathrm{Lab})$ \\
\hline $\begin{array}{l}\text { Leding et al. } \\
(2015)[\mathrm{CHB}]\end{array}$ & $\begin{array}{l}\text { Effects of an attractive avatar on the } \\
\text { perception of viewing actual human }\end{array}$ & $\begin{array}{l}\text { full body, static, 3D } \\
{[\mathrm{H} 2 \mathrm{~A}]}\end{array}$ & \begin{tabular}{|l} 
attractiveness \\
[social]
\end{tabular} & attractiveness & $\begin{array}{l}120(\mathrm{Lab}) \\
234(\mathrm{Lab})\end{array}$ \\
\hline
\end{tabular}




\begin{tabular}{|c|c|c|c|c|c|}
\hline $\begin{array}{l}\text { Authors (year) } \\
\text { [Outlet] }\end{array}$ & Brief Description & \begin{tabular}{|c|} 
Avatar / Embodied \\
Agent Design \\
[Interaction]
\end{tabular} & $\begin{array}{l}\text { Application } \\
\text { [Context] }\end{array}$ & $\begin{array}{l}\text { Psychological } \\
\text { Construct(s) }\end{array}$ & \#P (Env) \\
\hline $\begin{array}{l}\text { Nowak et al. } \\
\text { (2015) [JCMC] }\end{array}$ & $\begin{array}{l}\text { Effects of an avatar's clothing and } \\
\text { anthropomorphism on trust and } \\
\text { message clarity }\end{array}$ & $\begin{array}{l}\text { full body, static, 2D } \\
{[\mathrm{H} 2 \mathrm{~A}]}\end{array}$ & $\begin{array}{l}\text { dating or job } \\
\text { interview } \\
\text { [business] }\end{array}$ & $\begin{array}{l}\text { anthropomorphism, } \\
\text { appropriateness, } \\
\text { attractiveness, } \\
\text { credibility, trust }\end{array}$ & $397(\mathrm{Lab})$ \\
\hline $\begin{array}{l}\text { Ratan \& Sah } \\
(2015) \text { [CHB] }\end{array}$ & $\begin{array}{l}\text { Effects of an avatar's identity } \\
\text { characteristics on avatar users' } \\
\text { behaviours }\end{array}$ & $\begin{array}{l}\text { full body, motion, } \\
\text { 3D }[\mathrm{SA} 2 \mathrm{~A}]\end{array}$ & \begin{tabular}{|l} 
video game \\
[entertainment]
\end{tabular} & $\begin{array}{l}\text { engagement, } \\
\text { motivation, self- } \\
\text { representation, } \\
\text { presence, self- } \\
\text { relevance }\end{array}$ & 64 (Lab) \\
\hline $\begin{array}{l}\text { Sanchez-Valdes } \\
\text { \& Trivino (2015) } \\
{[\text { [ESWA] }}\end{array}$ & $\begin{array}{l}\text { Effects of an avatar emotion on users' } \\
\text { physical activities }\end{array}$ & $\begin{array}{l}\text { face only, static, 2D } \\
\text { [H2SA] }\end{array}$ & $\begin{array}{l}\text { physical } \\
\text { activity [health] }\end{array}$ & $\begin{array}{l}\text { emotionality, } \\
\text { motivation }\end{array}$ & 3 (Fld) \\
\hline $\begin{array}{l}\text { Westerman et al. } \\
(2015)[\mathrm{CHB}]\end{array}$ & $\begin{array}{l}\text { Effects of different types of avatars } \\
\text { created for social or dating/ romantic } \\
\text { situations on users }\end{array}$ & $\begin{array}{l}\text { half body, static, 2D } \\
{[\mathrm{H} 2 \mathrm{~A}]}\end{array}$ & $\begin{array}{l}\text { networking } \\
{[\text { social] }}\end{array}$ & $\begin{array}{l}\text { attractiveness, } \\
\text { intention to use, } \\
\text { similarity }\end{array}$ & $206(\mathrm{Lab})$ \\
\hline \begin{tabular}{|l} 
Won et al. \\
$(2015)[$ JCMC]
\end{tabular} & $\begin{array}{l}\text { Effects of an avatar's movement on } \\
\text { user's movements on the real world }\end{array}$ & $\begin{array}{l}\text { full body, motion, } \\
\text { 3D [H2SA] }\end{array}$ & $\begin{array}{l}\text { communication } \\
\text { [entertainment] }\end{array}$ & motivation, presence & $\begin{array}{l}53 \text { (Lab) } \\
20 \text { (Lab) }\end{array}$ \\
\hline $\begin{array}{l}\text { Wrzesien et al. } \\
(2015)[\mathrm{CHB}]\end{array}$ & $\begin{array}{l}\text { Influence of the physical similarity of } \\
\text { avatars on user's emotion regulation } \\
\text { training }\end{array}$ & $\begin{array}{l}\text { full body, motion, } \\
\text { 3D }[\mathrm{H} 2 \mathrm{~A} / \mathrm{H} 2 \mathrm{SA}]\end{array}$ & $\begin{array}{l}\text { emotion } \\
\text { regulation } \\
\text { [education] }\end{array}$ & similarity & 22 (Lab) \\
\hline $\begin{array}{l}\text { Wu et al. (2015) } \\
{[\mathrm{CHB}]}\end{array}$ & $\begin{array}{l}\text { The study explores the effects on } \\
\text { verbal behaviour in virtual interaction }\end{array}$ & $\begin{array}{l}\text { full body, motion, } \\
\text { 3D [SA2A] }\end{array}$ & $\begin{array}{l}\text { communication } \\
\text { [social] }\end{array}$ & $\begin{array}{l}\text { behavioural intention, } \\
\text { presence }\end{array}$ & $32(\mathrm{Lab})$ \\
\hline $\begin{array}{l}\text { Burgoon et al. } \\
\text { (2016) [IJHCS] }\end{array}$ & $\begin{array}{l}\text { Effects of an embodied agent on the } \\
\text { outcomes of decision-making tasks }\end{array}$ & $\begin{array}{l}\text { face only, motion, } \\
3 \mathrm{D}[\mathrm{H} 2 \mathrm{H} / \mathrm{H} 2 \mathrm{EA}]\end{array}$ & $\begin{array}{l}\text { communication } \\
\text { [business] }\end{array}$ & $\begin{array}{l}\text { attractiveness, } \\
\text { expectedness, } \\
\text { dependability, } \\
\text { receptiveness }\end{array}$ & $70(\mathrm{Lab})$ \\
\hline $\begin{array}{l}\text { Carlotto \& } \\
\text { Jaques }(2016) \\
{[\text { [JHCS] }}\end{array}$ & $\begin{array}{l}\text { Effects of an embodied agent on users' } \\
\text { in a learning environment }\end{array}$ & $\begin{array}{l}\text { full body, motion, } \\
\text { 2D [H2EA] }\end{array}$ & $\begin{array}{l}\text { learning } \\
\text { [education] }\end{array}$ & \begin{tabular}{|l|} 
expressiveness, \\
motivation, relevance, \\
satisfaction, \\
willingness to repeat
\end{tabular} & 72 (Lab) \\
\hline $\begin{array}{l}\text { Guegan et al. } \\
(2016)[\mathrm{CHB}]\end{array}$ & $\begin{array}{l}\text { Effects of avatars on users' creativity } \\
\text { Performance in collaborative meeting }\end{array}$ & $\begin{array}{l}\text { full body, motion, } \\
\text { 3D }[\mathrm{SA} 2 \mathrm{~A}]\end{array}$ & $\begin{array}{l}\text { meeting } \\
\text { [business] }\end{array}$ & similarity & $\begin{array}{l}114(\mathrm{Lab}) \\
54(\mathrm{Lab})\end{array}$ \\
\hline $\begin{array}{l}\text { H.-K. Kim \& } \\
\text { Kim }(2016) \\
{[\mathrm{CHB}]}\end{array}$ & $\begin{array}{l}\text { Explores the emotional bonds between } \\
\text { the individual and their avatar }\end{array}$ & $\begin{array}{l}\text { full body, motion, } \\
\text { 3D [SA2A] }\end{array}$ & driving [social] & $\begin{array}{l}\text { attractiveness, } \\
\text { emotional closeness, } \\
\text { similarity }\end{array}$ & $111(\mathrm{Lab})$ \\
\hline \begin{tabular}{|l} 
Li \& Lwin \\
$(2016)[\mathrm{CHB}]$
\end{tabular} & $\begin{array}{l}\text { Effects of self-avatars on user's } \\
\text { presence and enjoyment }\end{array}$ & $\begin{array}{l}\text { full body, motion, } \\
3 \mathrm{D}[\mathrm{H} 2 \mathrm{~A}]\end{array}$ & $\begin{array}{l}\text { video game } \\
\text { [entertainment] }\end{array}$ & \begin{tabular}{|l|} 
enjoyment, \\
identification, presence
\end{tabular} & $322(\mathrm{Lab})$ \\
\hline \begin{tabular}{|l} 
Peña et al. \\
(2016) [JCMC]
\end{tabular} & $\begin{array}{l}\text { Influences of avatar's body size on } \\
\text { physical activity using accelerometers }\end{array}$ & $\begin{array}{l}\text { full body, motion, } \\
\text { 3D [SA2EA] }\end{array}$ & $\begin{array}{l}\text { exergame } \\
\text { [entertainment] }\end{array}$ & $\mathrm{NA}$ & 96 (Lab) \\
\hline $\begin{array}{l}\text { Rodrigues et al. } \\
(2016)[\mathrm{CHB}]\end{array}$ & $\begin{array}{l}\text { Effects of avatars use in business } \\
\text { application on customers }\end{array}$ & $\begin{array}{l}\text { half body, static, 3D } \\
{[\mathrm{H} 2 \mathrm{~A}]}\end{array}$ & $\begin{array}{l}\text { gamification e- } \\
\text { banking app } \\
\text { [business] }\end{array}$ & $\begin{array}{l}\text { ease of use, enjoyment, } \\
\text { usefulness, intention to } \\
\text { use, presence }\end{array}$ & 183 (Fld) \\
\hline $\begin{array}{l}\text { Bacev-Giles \& } \\
\text { Haji (2017) } \\
{[\mathrm{CHB}]}\end{array}$ & $\begin{array}{l}\text { Examines impressions of avatar online } \\
\text { profiles for gender stereotype } \\
\text { impressions }\end{array}$ & $\begin{array}{l}\text { full body, static, 3D } \\
{[\mathrm{H} 2 \mathrm{~A}]}\end{array}$ & $\begin{array}{l}\text { interaction } \\
{[\text { social }]}\end{array}$ & $\begin{array}{l}\text { gender, likeability, } \\
\text { similarity }\end{array}$ & $239(\mathrm{Lab})$ \\
\hline \begin{tabular}{|l} 
Beege et al. \\
$(2017)$ [CHB]
\end{tabular} & $\begin{array}{l}\text { Investigates the influence of } \\
\text { stereotypes on learning, cognitive load } \\
\text { and motivation as well as time spent } \\
\text { with the embodied agent }\end{array}$ & $\begin{array}{l}\text { full body, motion, } \\
3 \mathrm{D}[\mathrm{H} 2 \mathrm{EA}]\end{array}$ & $\begin{array}{l}\text { health material } \\
\text { [health] }\end{array}$ & gender, similarity & 84 (Lab) \\
\hline $\begin{array}{l}\text { Balas \& Pacella } \\
(2017)[\mathrm{CHB}]\end{array}$ & $\begin{array}{l}\text { Examines the perceived } \\
\text { trustworthiness of avatars' and humans' } \\
\text { faces }\end{array}$ & $\begin{array}{l}\text { face only, static, 2D } \\
{[\mathrm{H} 2 \mathrm{~A}]}\end{array}$ & $\begin{array}{l}\text { interaction } \\
\text { [social] }\end{array}$ & sensitivity, trust & $\begin{array}{l}51 \text { (Lab) } \\
20 \text { (Lab) }\end{array}$ \\
\hline $\begin{array}{l}\text { Barata et al. } \\
(2017) \text { [CHB] }\end{array}$ & $\begin{array}{l}\text { Examines students' performance in } \\
\text { gamified collage course }\end{array}$ & $\begin{array}{l}\text { full body, motion, } \\
\text { 3D [H2SA] }\end{array}$ & $\begin{array}{l}\text { learning } \\
\text { [education] }\end{array}$ & $\begin{array}{l}\text { ease of use, continuity, } \\
\text { engagement }\end{array}$ & $\begin{array}{l}35 \text { N.A. } \\
52 \text { N.A. } \\
54 \text { (Fld) }\end{array}$ \\
\hline $\begin{array}{l}\text { Cobo et al. } \\
(2017) \text { [CHB] }\end{array}$ & $\begin{array}{l}\text { Examines distant exploration of places } \\
\text { and time spent with avatar for blind } \\
\text { people using smart phone }\end{array}$ & $\begin{array}{l}\text { full body, motion, } \\
3 \mathrm{D}[\mathrm{H} 2 \mathrm{SA}]\end{array}$ & $\begin{array}{l}\text { interaction } \\
{[\text { social }]}\end{array}$ & NA & 19 (Lab) \\
\hline
\end{tabular}




\begin{tabular}{|c|c|c|c|c|c|}
\hline $\begin{array}{c}\text { Authors (year) } \\
\text { [Outlet] }\end{array}$ & Brief Description & $\begin{array}{l}\text { Avatar / Embodied } \\
\text { Agent Design } \\
\text { [Interaction] }\end{array}$ & $\begin{array}{l}\text { Application } \\
\text { [Context] }\end{array}$ & $\begin{array}{l}\text { Psychological } \\
\text { Construct(s) }\end{array}$ & \#P (Env) \\
\hline $\begin{array}{l}\text { Dechant et al. } \\
(2017)[\mathrm{CHB}]\end{array}$ & $\begin{array}{l}\text { Examines virtual reality to diagnose } \\
\text { social anxiety }\end{array}$ & $\begin{array}{l}\text { full body, motion, } \\
\text { 3D [SA2EA] }\end{array}$ & $\begin{array}{l}\text { interaction } \\
{[\text { social }]}\end{array}$ & user anxiety & $119(\mathrm{Lab})$ \\
\hline $\begin{array}{l}\text { Fehrenbacher \& } \\
\text { Weisner (2017) } \\
{[\text { ICIS] }}\end{array}$ & $\begin{array}{l}\text { Examines knowledge sharing while } \\
\text { interacting with real human images vs } \\
\text { avatars }\end{array}$ & $\begin{array}{l}\text { face only, static, 3D } \\
{[\text { SA2A] }}\end{array}$ & $\begin{array}{l}\text { communication } \\
\text { [social] }\end{array}$ & $\begin{array}{l}\text { similarity (ethnicity), } \\
\text { trust }\end{array}$ & 97 (Lab) \\
\hline $\begin{array}{l}\text { Guegan et al. } \\
(2017) \text { [CHB] }\end{array}$ & $\begin{array}{l}\text { Examines the effects of visual cues of } \\
\text { social identity on group performance }\end{array}$ & $\begin{array}{l}\text { full body, motion, } \\
3 \mathrm{D}[\mathrm{SA} 2 \mathrm{~A}]\end{array}$ & $\begin{array}{l}\text { brainstorming } \\
\text { [business] }\end{array}$ & $\begin{array}{l}\text { identification, presence } \\
\text { (social cues) }\end{array}$ & 72 (Lab) \\
\hline $\begin{array}{l}\text { Hofer et al. } \\
(2017)[\mathrm{CHB}]\end{array}$ & $\begin{array}{l}\text { Examines the effects on avatars' } \\
\text { expression on users fear reactions. }\end{array}$ & $\begin{array}{l}\text { full body, motion, } \\
\text { 3D [H2SA/SA2A] }\end{array}$ & $\begin{array}{l}\text { video game } \\
\text { [entertainment] }\end{array}$ & $\begin{array}{l}\text { agency, physical } \\
\text { appearance (avatar } \\
\text { embodiment) }\end{array}$ & $\begin{array}{l}103(\mathrm{Lab}) \\
104(\mathrm{Lab})\end{array}$ \\
\hline $\begin{array}{l}\text { Khashe et al. } \\
(2017) \text { [CHB] }\end{array}$ & $\begin{array}{l}\text { Investigates influence of avatars' } \\
\text { communication style and gender on } \\
\text { user compliance }\end{array}$ & $\begin{array}{l}\text { half body, motion, } \\
3 \mathrm{D}[\mathrm{H} 2 \mathrm{~A}]\end{array}$ & $\begin{array}{l}\text { communication } \\
\text { [business] }\end{array}$ & $\begin{array}{l}\text { communication style, } \\
\text { gender }\end{array}$ & $214(\mathrm{Lab})$ \\
\hline $\begin{array}{l}\text { H. E. Kim et al. } \\
(2017) \text { [CHB] }\end{array}$ & $\begin{array}{l}\text { Examines the effects of mobile-based } \\
\text { self-training performance for social } \\
\text { anxiety }\end{array}$ & $\begin{array}{l}\text { full body, motion, } \\
\text { 3D [H2SA] }\end{array}$ & $\begin{array}{l}\text { self-training } \\
\text { [health] }\end{array}$ & avoidance & $22(\mathrm{Lab})$ \\
\hline $\begin{array}{l}\text { Kohonen-aho \& } \\
\text { Tiilikainen } \\
(2017)[\text { ICIS] }\end{array}$ & $\begin{array}{l}\text { Examines the effects of virtual world } \\
\text { in virtual team performance of } \\
\text { informal interaction }\end{array}$ & $\begin{array}{l}\text { full body, motion, } \\
3 \mathrm{D}[\mathrm{SA} 2 \mathrm{~A}]\end{array}$ & $\begin{array}{l}\text { virtual team } \\
\text { [business] }\end{array}$ & presence & $36(\mathrm{Lab})$ \\
\hline $\begin{array}{l}\text { Kothgassner et } \\
\text { al. (2017) }[\mathrm{CHB}]\end{array}$ & $\begin{array}{l}\text { Examines a virtual social exclusion } \\
\text { scenario and tests for behavioural } \\
\text { consequences }\end{array}$ & $\begin{array}{l}\text { full body, motion, } \\
\text { 3D }[\mathrm{SA} 2 \mathrm{~A} / \mathrm{SA} 2 \mathrm{EA}]\end{array}$ & $\begin{array}{l}\text { interaction } \\
{[\text { social] }}\end{array}$ & $\begin{array}{l}\text { emotional state, } \\
\text { presence, self-esteem }\end{array}$ & 45 (Lab) \\
\hline $\begin{array}{l}\text { S. Lee \& Choi } \\
(2017) \text { [IJHCS] }\end{array}$ & $\begin{array}{l}\text { Investigates embodied agents' } \\
\text { recommendations for movies on users' } \\
\text { experience and self-disclosure }\end{array}$ & $\begin{array}{l}\text { full body, motion, } \\
3 \mathrm{D}[\mathrm{H} 2 \mathrm{EA}]\end{array}$ & $\begin{array}{l}\text { online services } \\
\text { [business] }\end{array}$ & $\begin{array}{l}\text { enjoyment, intention to } \\
\text { use, satisfaction }\end{array}$ & $225(\mathrm{Lab})$ \\
\hline $\begin{array}{l}\text { Peña \& Chen } \\
(2017) \text { [CHB] }\end{array}$ & $\begin{array}{l}\text { Examines how activating prosocial } \\
\text { and antisocial concepts affect } \\
\text { successive prosocial behaviours and } \\
\text { intentions }\end{array}$ & $\begin{array}{l}\text { full body, motion, } \\
\text { 3D [H2SA] }\end{array}$ & $\begin{array}{l}\text { video game } \\
\text { [entertainment }]\end{array}$ & $\begin{array}{l}\text { prosocial behaviour } \\
\text { (helping), prosocial } \\
\text { intention }\end{array}$ & 309 (Lab) \\
\hline $\begin{array}{l}\text { Schneider et al. } \\
(2017) \text { [CHB] }\end{array}$ & $\begin{array}{l}\text { Examines the effects of online } \\
\text { exclusion }\end{array}$ & $\begin{array}{l}\text { face only, static, 2D } \\
{[\mathrm{H} 2 \mathrm{~A}]}\end{array}$ & $\begin{array}{l}\text { interaction } \\
{[\text { social] }}\end{array}$ & $\begin{array}{l}\text { belongingness, } \\
\text { emotional state, self- } \\
\text { esteem }\end{array}$ & $\begin{array}{l}105(\mathrm{Lab}) \\
85(\mathrm{Lab})\end{array}$ \\
\hline $\begin{array}{l}\text { Sebastian \& } \\
\text { Richards (2017) } \\
{[\mathrm{CHB}]}\end{array}$ & $\begin{array}{l}\text { Examines the effects of educational } \\
\text { embodied agents on performance of } \\
\text { mental health patients using videos for } \\
\text { intervention }\end{array}$ & $\begin{array}{l}\text { half body, motion, } \\
\text { 3D [H2EA] }\end{array}$ & training [health] & NA & $245(\mathrm{Lab})$ \\
\hline $\begin{array}{l}\text { Seo et al. (2017) } \\
{[\mathrm{CHB}]}\end{array}$ & $\begin{array}{l}\text { Investigates self-presence when users } \\
\text { are exposed to self-avatars }\end{array}$ & $\begin{array}{l}\text { face only, static, 3D } \\
{[\mathrm{H} 2 \mathrm{SA}]}\end{array}$ & $\begin{array}{l}\text { interaction } \\
{[\text { social }]}\end{array}$ & $\begin{array}{l}\text { identification, } \\
\text { presence, similarity }\end{array}$ & 25 (Lab) \\
\hline $\begin{array}{l}\text { Tamborini et al. } \\
(2018) \text { [CHB] }\end{array}$ & $\begin{array}{l}\text { Examines the effect of embodied } \\
\text { agents' ethnicity on trust }\end{array}$ & $\begin{array}{l}\text { motion, full body, } \\
3 \mathrm{D}[\mathrm{H} 2 \mathrm{EA}]\end{array}$ & \begin{tabular}{|l} 
video game \\
[entertainment $]$
\end{tabular} & $\begin{array}{l}\text { similarity (ethnicity), } \\
\text { trust }\end{array}$ & $205(\mathrm{Lab})$ \\
\hline $\begin{array}{l}\text { Felnhofer et al. } \\
(2018) \text { [CHB] }\end{array}$ & $\begin{array}{l}\text { Investigating social avoidance and } \\
\text { prosocial behaviour towards avatars } \\
\text { and agents }\end{array}$ & $\begin{array}{l}\text { full body, motion, } \\
\text { 3D }[\mathrm{SA} 2 \mathrm{~A} / \mathrm{SA} 2 \mathrm{EA}]\end{array}$ & $\begin{array}{l}\text { interaction } \\
{[\text { social }]}\end{array}$ & $\begin{array}{l}\text { agency, empathy } \\
\text { presence, user anxiety }\end{array}$ & $95(\mathrm{Lab})$ \\
\hline $\begin{array}{l}\text { Kaye et al. } \\
(2018)[\mathrm{CHB}]\end{array}$ & $\begin{array}{l}\text { Examines the effects of explicit } \\
\text { priming and avatar gender }\end{array}$ & $\begin{array}{l}\text { full body, motion, } \\
3 \mathrm{D} \text { [H2SA] }\end{array}$ & \begin{tabular}{|l} 
video game \\
[entertainment]
\end{tabular} & $\begin{array}{l}\text { competence, identity, } \\
\text { self-esteem }\end{array}$ & $120(\mathrm{Lab})$ \\
\hline $\begin{array}{l}\text { Martens et al. } \\
(2018) \text { [CHB] }\end{array}$ & $\begin{array}{l}\text { Examines avatars' and users' difference } \\
\text { and similarities on time spent with } \\
\text { avatar }\end{array}$ & $\begin{array}{l}\text { full body, motion, } \\
3 \mathrm{D}[\mathrm{SA} 2 \mathrm{~A}]\end{array}$ & $\begin{array}{l}\text { video game } \\
\text { [entertainment] }\end{array}$ & similarity & $124(\mathrm{Lab})$ \\
\hline $\begin{array}{l}\text { Mousas et al. } \\
(2018)[\mathrm{CHB}]\end{array}$ & $\begin{array}{l}\text { Examines the effects of appearance } \\
\text { and motion of embodied agents on } \\
\text { users' emotional reactivity }\end{array}$ & $\begin{array}{l}\text { half body, motion, } \\
\text { 3D [H2EA] }\end{array}$ & $\begin{array}{l}\text { virtual } \\
\text { character } \\
\text { [entertainment] }\end{array}$ & $\begin{array}{l}\text { emotional reactivity, } \\
\text { emotional valence }\end{array}$ & 72 (Lab) \\
\hline
\end{tabular}

Note: MISQ: Management Information System Quarterly; JMIS: Journal of Management Information System; ISJ: Information System Journal; ESWA: Expert Systems with Application; DSS: Decision Support System; JCMC: Journal of Computer-Mediated Communication; ICIS: International Conference on Information System; IJHCS: International Journal of Human Computer Studies; CHB: Computer in Human Behaviors; H2H: human to human interaction; NA: not applicable; lab: laboratory experiment, srv: survey; Fld: field; N.A.: No Avatars used; \#P: Number of Participants; 2D: Two dimensional; 3D: Three dimensional; Env.: interaction environment 


\section{Acknowledgement}

The first author would like to acknowledge the full scholarship from the Institute of Public Administration (IPA) in the Kingdom of Saudi Arabia to study a PhD degree in IS at the University of Newcastle, Australia. We would also like to thank the editor and two anonymous reviewers for their insightful feedback and suggestions, which assisted in improving the overall quality of the paper.

Copyright: (c) 2019 Aljaroodi, Adam, Chiong \& Teubner. This is an open-access article distributed under the terms of the Creative Commons Attribution-NonCommercial 3.0 Australia License, which permits non-commercial use, distribution, and reproduction in any medium, provided the original author and AJIS are credited.

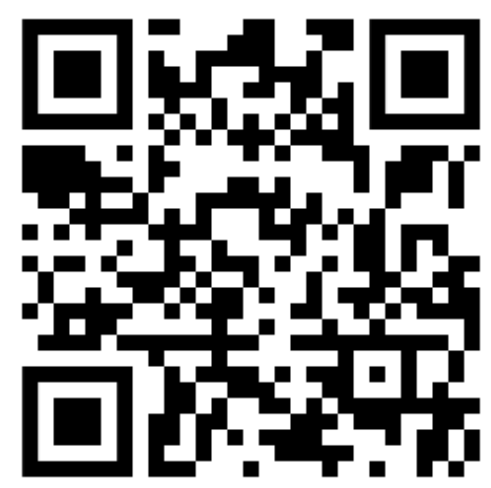

